\title{
Linking mineralisation process and sedimentary product in terrestrial carbonates using a solution thermodynamic approach
}

\author{
M. Rogerson, H. M. Pedley, A. Kelham, and J. D Wadhawan \\ Department of Geography, Environment and Earth Sciences, University of Hull, Cottingham Road, Hull, \\ HU6 7RX, UK
}

Correspondence to: M. Rogerson (m.rogerson@hull.ac.uk)

Received: 17 August 2013 - Published in Earth Surf. Dynam. Discuss.: 11 September 2013

Revised: 6 February 2014 - Accepted: 14 February 2014 - Published: 1 April 2014

Abstract. Determining the processes which generate terrestrial carbonate deposits (tufas, travertines and to a lesser extent associated chemical sediments such as calcretes and speleothems) is a long-standing problem. Precipitation of mineral products from solution reflects a complex combination of biological, equilibrium and kinetic processes, and the different morphologies of carbonate sediment produced by different processes have yet to be clearly demarked. Building on the groundbreaking work of previous authors, we propose that the underlying control on the processes leading to the deposition of these products can be most parsimoniously understood from the thermodynamic properties of their source solutions. Here, we report initial observations of the differences in product generated from spring and lake systems spanning a range of temperature-supersaturation space. We find that at high supersaturation, biological influences are masked by high rates of physico-chemical precipitation, and sedimentary products from these settings infrequently exhibit classic "biomediated" fabrics such as clotted micrite. Likewise, at high temperature $\left(>40^{\circ} \mathrm{C}\right)$ exclusion of vascular plants and complex/diverse biofilms can significantly inhibit the magnitude of biomediated precipitation, again impeding the likelihood of encountering the "bio-type" fabrics.

Conversely, despite the clear division in product between extensive tufa facies associations and less spatially extensive deposits such as oncoid beds, no clear division can be identified between these systems in temperature-supersaturation space. We reiterate the conclusion of previous authors, which demonstrate that this division cannot be made on the basis of physico-chemical characteristics of the solution alone. We further provide a new case study of this division from two adjacent systems in the UK, where tufa-like deposition continuous on a metre scale is happening at a site with lower supersaturation than other sites exhibiting only discontinuous (oncoidal) deposition. However, a strong microbiological division is demonstrated between these sites on the basis of suspended bacterial cell distribution, which reach a prominent maximum where tufa-like deposits are forming.

We conclude that at high supersaturation, the thermodynamic properties of solutions provide a highly satisfactory means of linking process and product, raising the opportunity of identifying water characteristics from sedimentological/petrological characteristics of ancient deposits. At low supersaturation, we recommend that future research focuses on geomicrobiological processes rather than the more traditional, inorganic solution chemistry approach dominant in the past. 


\section{Introduction}

Terrestrial carbonate deposits have outstanding potential to act as an archive of climatic change (Andrews, 2006) and/or changes in the behaviour of crustal fluids (Minissale, 2004). However, despite their high potential and the considerable research effort that has already been expended on them, there remains considerable debate and confusion over how mineral-forming processes can be linked to the sedimentology and petrology of tufas, travertines and other terrestrial chemical deposits. General recognition of the importance of terrestrial carbonate systems and deposits has never been higher. There is pressing need for more and better archives of past climatic and environmental change from the Holocene (Hori et al., 2008) to the Palaeoproterozoic (Brasier, 2014). Combined with this, the increasing focus on geochemical methods to provide proxies for reconstruction of the past means that having certainty that particular deposit records meteoric (or geothermal) processes is of fundamental importance. The discovery of terrestrial carbonate reservoirs hosting significant oil reserves in the South Atlantic (Wright, 2012) and recent suggestions that the carbon sink represented by these systems may be globally important (Liu et al., 2010) have yet further emphasised that our understanding of terrestrial carbonate production must be improved. In particular, it is a basic requirement that meteoric and geothermal processes can be disentangled before a fossil deposit can be understood, and we currently lack the tools and knowledge by which to make this distinction (Wright, 2012).

Early efforts to classify terrestrial carbonate deposits were based on straightforward applications of conventional carbonate petrographic schemes. The standard scheme of Dunham (1962) modified by Embury and Kloven (1972) works admirably for most freshwater limestones (for example, most laminated, microbial components are recognisably "boundstones"), but either has very little precision or is excessively overcomplicated (depending on how the basic scheme is modified) on account of the numerous biological elements present. These classifications also make no attempt to link product to process. Considerable advances from these early efforts have been made for geothermal deposits by numerous authors (Chafetz and Folk, 1984; Folk and Chafetz, 1983; Carrara et al., 1998; Carrara, 1994; Folk, 1994; Folk et al., 1985) and a useful overview of geothermal systems has been provided by Guo and Riding (1998). Much of the current petrographic terminology applied to ambient temperature tufas has also developed upon the Folk and Dunham schemes (see Pentecost, 2005). However, to date no single petrographic scheme has proven sufficiently effective to become standard for use in ambient temperature carbonate systems.

In contrast, a diverse group of field classification schemes have independently been developed specifically for freshwater carbonates (Stirn, 1964; Irion and Müller, 1968; Schneider et al., 1983; Pentecost and Lord, 1988) emphasising the role of botanical elements (Pentecost and Lord, 1988), their distinct geomorphological expression within the landscape (Symoens et al., 1951; Golubić, 1969; Nicod, 1981; Szulc, 1983), or combinations of biological and geomorphological aspects (Buccino et al., 1978; Ferreri, 1985; D’Argenio and Ferreri, 1988; Golubić et al., 1993). Others (e.g Julia, 1983; Golubić, 1969) have discussed a process-based approach frequently involving cyclic progression of the facies, and an important observation to arise from more recent classifications was the role played by the phytoherm (freshwater reef) in tufa accumulation (see discussion in Pedley (1992, 1990). This work was drawn together by Pedley (1990) and Ford and Pedley (1997), who offered an integrated, rationalised scheme for classifying freshwater carbonates which embraced both laboratory and field scales. Modifications of these schemes are now available for tropical tufas (e.g. (Carthew et al., 2006) and new controls on the processes controlling individual facies are being provided by continuing field (Drysdale et al., 2003b; Brasier et al., 2011) and laboratory-based research (Pedley and Rogerson, 2010b). Alternative field classifications continue to evolve (e.g. Glover and Robertson, 2003, and Peña et al., 2000, for ambient temperature systems, and Veysey II et al., 2008, for geothermal systems), and increasingly recognise the importance of the processes that control the distribution of specific products (Fouke et al., 2000, 2003). However, these schemes are rather site-specific and are yet to be updated to reflect recent developments in understanding biofilm processes (Decho, 2010).

Despite considerable progress on ambient and geothermal systems in isolation, little progress has been made towards a single scheme that adequately discriminates both geothermal and meteoric-type deposits simultaneously. Attempts have been made to bridge and update existing classification schemes to also encompass geothermal deposits (e.g. Jones and Renaut, 2010), but these remain focussed on products at the expense of knowledge about processes. In this regard, it is surprising that there has not yet been an attempt to classify these deposits on the basis of whether they are dominantly biomediated or physico-chemical deposits. In the light of new insights into these processes arising from experimental work (Pedley and Rogerson, 2010a; Pedley et al., 2009; Bissett et al., 2008a; Shiraishi et al., 2008b), this is a major shortcoming.

Ultimately, we are yet to achieve the goal of a universally effective classification for terrestrial deposits that adequately reflects their unique modes of origin. Understanding how processes can be read from products is a key step to achieve this goal. Major stumbling blocks remain to achieving this goal, however. Most seriously, the independent development of terminology between ambient temperature deposits and thermal deposits maintains the division of these two research communities. Even the basic terminology distinguishing terrestrial carbonates is not without conflict as some workers (e.g. Pentecost, 2005; Pentecost and Viles, 1994) recommend that all freshwater deposits should be called travertines, with the caveat that the prefixes "meteogene" or "thermogene" 
be applied for deposits in which the original precipitating source waters are either cool, shallow circulation-meteoric or hot, deep circulation (thermogene, with temperatures typically $20-60^{\circ} \mathrm{C}$ at the point of emergence). Others (including the authors of this manuscript) recommend that travertine is reserved only for deposits in geothermal settings. The pressing need to see all terrestrial carbonate systems as related and not independent of each other is emphasised by the case of all "thermogene" or "travertine" systems, where vegetation colonisation occurs as waters cool towards ambient temperatures, resulting in deposits which are often indistinguishable from "meteogene" "tufas". While we argue that there is an advantage in retaining the terms "tufa" and "travertine" to distinguish between systems essentially driven by geothermal processes from meteoric processes, we simultaneously recognise that the downside of a simple division in terms of temperature is that alkaline lakes (e.g. Mono Lake, Connell and Dreiss, 1995) may generate deposits significantly different to normal "tufa" regardless of being ambient in terms of temperature.

Here, we attempt the first steps to overcome these stumbling blocks, building on the huge progress made in understanding the relationships between various types of deposits by previous workers outlined above, and propose a new direction in summarising precipitating system solution chemistry using simple thermodynamic concepts. Our thermodynamic approach is based on the assumption that physicochemical forcing of precipitation will ultimately be a product of strongly negative Gibbs free energy of calcite precipitation, as first proposed by Dandurand (Dandurand et al., 1982). Gibbs free energy, as we use the concept here, therefore reflects the chemical potential of the system to undergo a change (Langmuir, 1997). The change we are interested in is the conversion of calcium and carbonate ions into solution to a combined mineralogical phase. The Gibbs energy therefore represents the potential of the chemical systems to change spontaneously. This ability to change must arise from another chemical process, often related to changes in the abundance of carbonate ions due to exchange of $\mathrm{CO}_{2}$ gas at the air-water interface. However, there is considerable underlying complexity in understanding how the Gibbs free energy arises in the whole range of solutions possible in terrestrial carbonate systems. The chemical potential promoting precipitation could be outgassing of $\mathrm{CO}_{2}$ or indeed ingassing of the same gas, especially in anthropogenic sites (Andrews et al., 1997). The ionic strength of the solution, which is allied to the salinity of the solution, reduces the ability of ions to collide and so to react and form a mineral. Consequently, precipitation of non-calcium or carbonate bearing mineral phases could be key in some sites. Mixing of very strong solutions arising from deep crustal sources with more dilute solutions near the surface could also cause a rise in saturation, so long as the weaker solution has significant calcium and/or carbonate concentration. Rather than attempt to identify the origin of the chemical potential at every individual site, we recom- mend that an assessment of the Gibbs free energy as a representation of chemical potential is sufficient to describe the magnitude of the driving force behind precipitation regardless of its origin.

\subsection{Carbonate precipitation mechanisms in terrestrial, open-water settings}

\subsubsection{Hydrochemical controls}

To drive rapid precipitation, high levels of excess dissolved calcium carbonate are necessary in the ambient water. Consequently, the primary partition between tufa-forming and nontufa river systems should coincide with some threshold in calcite supersaturation. However, Pentecost (1992) showed that in the Yorkshire Dales (UK) no systematic relationship between precipitation and degree of calcium carbonate supersaturation was present. An additional problem of this view is that the activation energy for calcite is $-48.1 \mathrm{~kJ} \mathrm{~mol}^{-1}$ (Inskeep and Bloom, 1985) whereas the underlying physical process promoting this, the degassing of $\mathrm{CO}_{2}$, provides comparatively little driving-force (e.g. $\sim 5 \mathrm{~kJ} \mathrm{~mol}^{-1}$; Dandurand et al., 1982), leaving a wide energetic gap. It is therefore already abundantly clear that thermodynamic considerations are not sufficient to explain site-to-site differences at low supersaturation, that kinetic and "surface" conditions are responsible for driving mineral precipitation. Explanations of these additional conditions must be sought.

At higher supersaturation, physico-chemical precipitation (i.e. that regulated by classic equilibrium considerations) occurs either due to ingassing of atmospheric $\mathrm{CO}_{2(\mathrm{~g})}$ under hyperalkaline conditions due to the presence of excess $\mathrm{OH}_{(\mathrm{aq})}^{-}$ (Clark and Fontes, 1990; Andrews et al., 1997) or, more normally, due to outgassing of $\mathrm{CO}_{2}$ to atmosphere due to the presence of excess $\mathrm{HCO}_{3(\mathrm{aq})}^{-}$(Emeis et al., 1987). Rapid loss of $\mathrm{CO}_{2 \text { (aq) }}$ primarily occurs when fresh spring waters come into contact with air depleted in $\mathrm{CO}_{2}$ relative to aquifer air (Chafetz and Folk, 1984). Degassing-driven precipitation occurs according to the le Chatellier principle via

$\mathrm{HCO}_{3 \text { (aq) }}^{-}+\mathrm{Ca}_{\text {(aq) }}^{2+} \rightarrow \mathrm{CO}_{2 \text { (atm) }}+\mathrm{H}_{2} \mathrm{O}_{\text {(liquid) }}+\mathrm{CaCO}_{3 \text { (solid) }}$.

A consequence of this is that $\mathrm{HCO}_{3(\text { (aq })}^{-}$rapidly decreases downstream from point sources of spring water, driving rapid precipitation close to the spring and decreasing rate of precipitation in a downstream direction (Chen et al., 2004; Lorah and Herman, 1988; Merz-Preiss and Riding, 1999). A complicating factor is that calcite does not precipitate directly from bicarbonate, making the $\mathrm{pH}$-related conversion of $\mathrm{HCO}_{3(\mathrm{aq})}^{-}$to $\mathrm{CO}_{3(\mathrm{aq})}^{2-}$ potentially limiting of precipitation rate (Dreybrodt et al., 1997). This is demonstrated by the observation that precipitation can be slow immediately adjacent to the spring, but rapid a few 10s or 100s of metres downstream (Dandurand et al., 1982). Turbulent flow and active agitation increases the area of the air-water interface and therefore promotes gas exchange. Consequently, precipitation is 
considered to be enhanced at waterfalls and rapids by the same mechanism as occurs at springs (Chen et al., 2004), although physical calculations suggest this change is actually rather small (Hammer et al., 2010).

Carbon dioxide solubility is also strongly affected by temperature and evaporation will further promote increased supersaturation. Water at $0^{\circ} \mathrm{C}$ is capable of dissolving about three times as much $\mathrm{CO}_{2}$ as at $30^{\circ} \mathrm{C}$ (Dramis et al., 1999) and as cold karst waters emerge its temperature increases, resulting in $\mathrm{CO}_{2}$ outgassing and enhancing supersaturation of the water (Lorah and Herman, 1988). Mixing and high surface area: volume ratios promote warming, and consequently may potentially be enhanced at rapids and waterfalls, potentially overcoming the apparently minor changes in gas exchange expected from physical calculations. In temperate climates, slower downstream warming may result in reduced precipitation at proximal sites while warmer climates encourage more tufa formation closer to the spring (Drysdale et al., 2003a). High ambient air temperatures and low relative humidities will enhance levels of saturation, which is an important driver of precipitation in tropical tufa systems (Carthew et al., 2006; Drysdale and Gale, 1997). The impact of temperature and humidity can be large enough to significantly alter the large-scale morphology of major tufa systems, with high rates of precipitation reported from tufa systems in Spain relative to otherwise similar systems in the UK (Pedley et al., 1996).

In addition to these equilibrium processes acting in favour of precipitation, kinetic influences arising from degassing may also have significant impact, and may be particularly critical to initiating nucleation (Dandurand et al., 1982). If kinetics are dominant, different reaches and even different layers of water at a single reach of a freshwater system may have very different saturation characteristics. Surface layer kinetic influences (e.g. gas exchange) will ultimately be bound up with water flow structure, which regulates vertical ion transport rates. These authors are not aware of any specific study of flow structure in these settings. In contrast, bottom layer kinetic influences are well understood.

\subsubsection{Bottom layer kinetic influences; the diffusive boundary layer}

At sites with flowing water, flow separation occurs at the water-carbonate interface, forming a boundary layer across which ions are exchanged primarily by diffusion (Zaihua et al., 1995; Liu and Dreybrodt, 1997; Dreybrodt and Buhmann, 1991). Consequently, precipitation-inhibiting $\mathrm{H}^{+}$ions tend to accumulate at the water-carbonate interface via precipitation originating from bicarbonate:

$\mathrm{HCO}_{3(\mathrm{aq})}^{-}+\mathrm{Ca}_{(\mathrm{aq})}^{2+} \rightarrow \mathrm{CaCO}_{3 \text { (solid) }}+\mathrm{H}_{(\mathrm{aq})}^{+}$.

This drives down $\mathrm{pH}$, causing conversion of $\mathrm{CO}_{3 \text { (aq) }}^{2-}$ to $\mathrm{HCO}_{3(\mathrm{aq})}^{-}$and reducing saturation. Investigation of tufa depositing rivers in China (Zaihua et al., 1995) showed that the consequence of this behaviour was that deposition rates in fast flowing water are higher than still water by a factor of four. This mechanism has also been investigated via numerical modelling, which suggests that it may be a fundamental control on the patterns of development of tufa barrages (Hammer et al., 2007, 2008; Hammer, 2008; Veysey and Goldenfeld, 2008). Indeed, a degree of consensus is emerging from this work that "equilibrium" degassing at sites of enhanced flow has very little impact on the rate of precipitation, which is essentially driven by enhanced vertical ion flux, particularly where flows become unstable (Hammer et al., 2010). This consensus in the physical literature is yet to be fully recognised in the sedimentological literature.

\subsection{Biological factors}

The mechanisms and state of knowledge of microbially induced and influenced calcite precipitation has recently been thoroughly reviewed (Dupraz et al., 2009). Consequently, we here aim to only summarise the most relevant parts of the very extensive knowledge concerning microbe-calcite interaction.

\subsubsection{Photosynthesis and respiration}

Consumption of $\mathrm{CO}_{2}$ by photosynthesis results in raised $\mathrm{pH}$, and consequently in increased proportion of dissolved inorganic carbon present as $\mathrm{CO}_{3(\mathrm{aq})}^{2-}$, close to the bodies of microand macrophytes as well as phototrophic microbes such as cyanobacteria. Consequently, when photosynthesis occurs in solutions at or near saturation with respect to $\mathrm{CaCO}_{3}$, calcite may precipitate as sheaths around algal filaments and coatings on plants (Pentecost, 1978, 1987). Respiration operates in the inverse sense, tending to increase dissolved $\mathrm{CO}_{2}$ levels, reduce $\mathrm{pH}$ and inhibit precipitation. Consequently, tufa systems exist within a dynamic equilibrium where precipitation may be triggered or prevented by the balance of microbial metabolic processes (Visscher and Stolz, 2005; Decho, 2010). This balance will primarily reflect the state of health of the biofilm itself, as a growing community must, by definition, be consuming more carbon than it is releasing and vice versa. The impact of microbial metabolisms is well reflected in an investigation of chemical fluxes associated with calcite precipitating solutions, which indicates increased flux of $\mathrm{Ca}^{2+}$ and $\mathrm{HCO}_{3}^{-}$to biofilm-encrusted surfaces relative to non-encrusted surfaces in high light conditions, but the reverse under dark conditions (Shiraishi et al., 2008a). Curiously, biofilms are capable of modifying their microenvironment so that the $\mathrm{pH}$ of interstitial water remains constant regardless of changes in the macroenvironment (Bissett et al., 2008b), so this effect may actually be amplified under low ambient $\mathrm{pH}$ conditions. The observation of almost invariable $\mathrm{pH}$ within the biofilm has considerable significance for earlier ideas concerning the spatial control on tufa deposition, and potentially is one of the most important 
single observations made in this subject. For example, Pentecost (1992) suggested that the absence of tufa in certain streams in Yorkshire may reflect sporadic influxes of low $\mathrm{pH}$ water that would not be evident in field data derived from spot sampling. As the biofilm would buffer the growing tufa surface from such a change, this suggestion is now very difficult to sustain.

The degree to which photosynthesis alters the precipitation process has been debated for several decades (Shiraishi et al., 2008a). Monitoring of hydrochemical conditions over four diurnal cycles at a single station in Davys Creek, Australia, revealed little impact. Atmospheric temperature was identified as the dominant control on the $\mathrm{CO}_{2 \text { (aq) }}$ budget, implying that metabolic processes were of minor importance (Drysdale et al., 2003a). Conversely, studies of precipitation over diurnal cycles in China (Liu et al., 2008), Turkey (Bayari and Kurttas, 1995) and the UK (Spiro and Pentecost, 1991) indicate that macrophytes, algae and cyanobacteria play a dominant role in regulating precipitation rate. Laboratory studies indicate that precipitation to carbonate surfaces on the flow bed does not occur in the absence of biofilm (Shiraishi et al., 2008a, b; Pedley et al., 2009), and that photosynthesis may be critical to overcoming the energetic barrier to precipitation (Shiraishi et al., 2008a). This concept is given strong support by repeated observation of calcification of Charophyta bodies within water masses otherwise incapable of precipitating calcite (Anadon et al., 2002; Eremin et al., 2007; Pentecost et al., 2006). However, these effects still await proper quantification.

\subsubsection{Organic hydrogel templating}

The state of knowledge of "templating" - i.e. precipitation of calcite onto organic hydrogels - has recently been thoroughly reviewed (Decho, 2010), and we recommend this paper to interested readers. To avoid duplication here, we provide only a summary of the salient points. Templating is a well known, and widely used, means of accelerating, controlling and initiating mineral precipitation (Decho, 2010). Although it has been demonstrated that the chelation of $\mathrm{Ca}^{2+}$ ions to the natural organic gels formed by extracellular polymeric saccharides (EPS) in biofilms can be an inhibiting factor in carbonate mineral precipitation in seawater (Kawaguchi and Decho, 2002), in vitro experiments have shown this may not be the case in a freshwater setting with low ionic strength (Pedley et al., 2009; Rogerson et al., 2008). This appears to be a result of the fact that cation binding to EPS in these settings is more likely to be partial, with some aqueous ligands remaining intact (Saunders et al., 2014). As EPS gels generally account for between 50 and $90 \%$ of the total organic matter of a biofilm (Wingender et al., 1999), the possibility that organic binding can be a first-order control on precipitation means that metalorganic intermediaries may play a critical role in determining both rate and character of carbonate precipitate in terrestrial settings (Rogerson et al., 2010; Saunders et al., 2014).

As hinted above, the key process in regulating whether EPS promotes or impedes mineralisation is the immobilisation of calcium ions by anionic functional groups on EPS molecules (Decho, 2010). Understanding this process is still in its infancy, and highly dependent on nano-scale variations in EPS composition, which regulates the behaviour of the electrostatic properties of "microdomains". Promotion of precipitation is most likely to be enhanced where divalent cation binding is unidentate (i.e. only one electron volt of charge in the cation is offset by the ligands binding it to the organic molecule). Unidentate binding will considerably reduce the activation energy barrier which usually limits spontaneous precipitation (Dittrich and Sibler, 2010), making a significant contribution to promoting mineralisation. "Biologically influenced" precipitation arising from biopolymer templating is expected to deviate from "normal" physicochemical precipitation in terms of location, rate, morphology and chemistry. Before inference of a past environmental change can be inferred, it is therefore critical to determine whether "bio-influence" has been significant, or not. However, these processes remain understood only at descriptive levels and a means of distinguishing bio-mediated, bioinfluenced and non-biological precipitation remains a major target for the research community (Decho, 2010).

\subsubsection{Extracellular enzyme activity}

As of the date of submission, we are not aware of any study specifically investigating the behaviour of extracellular enzyme activity in tufa systems. However, their role in regulating $\mathrm{Ca}^{2+}$ dynamics in karst soils ( $\mathrm{Li}$ et al., 2007, 2005) and associated with cyanobacterial activity in soda lakes (Kupriyanova et al., 2003) and marine stromatolites (Kupriyanova et al., 2007) is well established and they are anticipated to be material to the mechanisms of "bio-influence" outlined in the preceding section (Decho, 2010). It may be that synthesis of these enzymes are partly responsible for the ability of biofilms to regulate their internal $\mathrm{pH}$ (Bissett et al., 2008b), and they are therefore material to understanding why the lower limit of precipitation of calcite (in terms of saturation) is so difficult to define (see Sect. 1.1.1).

\subsubsection{Biofilms as bioreactors}

It should be kept in mind that even when ambient water is fully oxygenated, the deeper parts of biofilms can routinely provide a substrate in which bacteria with anaerobic metabolism may flourish, often inhabiting niches within the sediment itself (Shiraishi et al., 2008c; Visscher and Stolz, 2005). Even when oxygen is available, local water chemistry may permit a wide range of metabolisms to be altering carbonate chemistry at a specific site (Fouke et al., 2003). Complex biofilm ecologies combine to create an "alkalinity 
Table 1. Summary of microbial metabolic biogeochemistries, with full bicarbonate buffering. Adapted from Visscher and Stolz (2005).

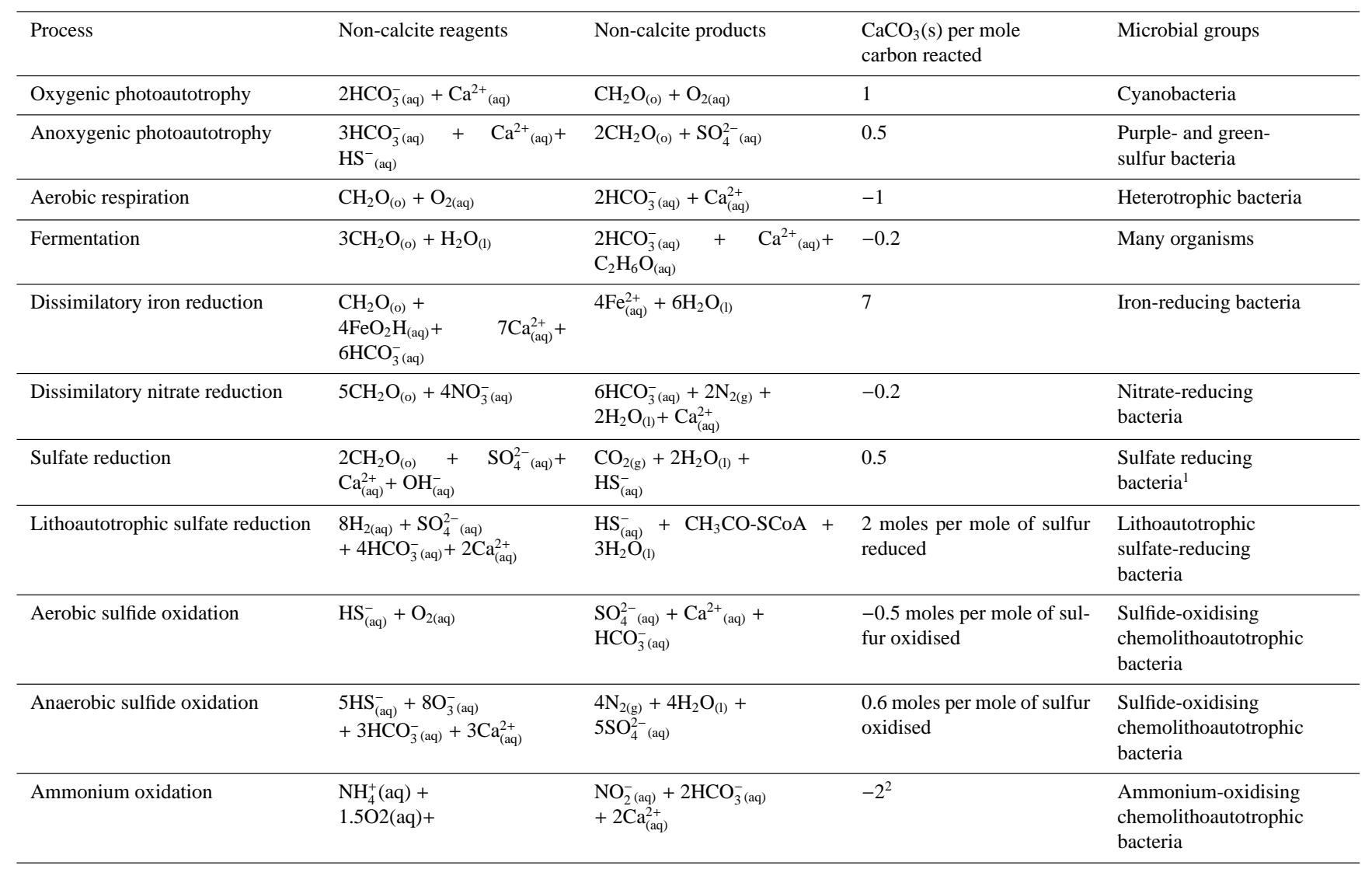

${ }^{1} \mathrm{Can}$ be up to 1.5 moles $\mathrm{CaCO}_{3}$ per mole of carbon oxidised with certain "complete oxidation" metabolisms. ${ }^{2}$ Balanced by precipitation of 1 mole per mole of carbon fixed from $\mathrm{CO}$ (aq) via the Calvin cycle. NB: other metabolic mechanisms such as two-step sulfide oxidation could be relevant, but only via variable microdomain ecology.

engine", the regulation, operation and impact of which are only partially understood (Dupraz et al., 2009). In solutions buffered by bicarbonate, anaerobic metabolisms will either promote or impede precipitation, depending on the specific stoichiometry of the electron donation-absorption system (Visscher and Stolz, 2005), as summarised in Table 1. Given the range of chemistries possible in alkaline spring systems, any specific microbial metabolism may be occurring at some site within the biofilm, meaning that many processes are simultaneously driving changes in the alkalinity engine. Although few detailed studies of them have been undertaken, "bioreactor" processes are probably highly site specific. For example, anaerobic sulfide oxidation by Aquificales spp. is clearly of fundamental importance at Angel Terrace, Yellowstone, USA; (Fouke et al., 2003), but is unlikely to be significant in karstic settings where reduced sulfur in solution is not abundant. In karstic settings, the most likely anaerobic metabolism found is sulfate reduction, as small amounts of sulfate are common in these solutions. Regardless, there is an apparent tendency for bioreactor processes to favour mineralisation of calcite. This deserves further investigation.

\section{Methods and source of case study data}

If we are to discriminate systems on the basis of whether biologically induced/influenced calcite precipitation is significant, and whether this precipitation is related to simple (exclusively microbial) or more complex ecologies (involving macrophytes) we first need to assess the chemical potential of the solution to promote physico-chemical precipitation of calcite.

In this study, we recommend using a thermodynamic representation of the calcite precipitation system rather than the more traditional saturation index. This is primarily due to the temperature range inherent in our data set, which is $>90^{\circ} \mathrm{C}$. Temperature is a first-order control on chemical reactions, and the key advantage of our recommended parameter, Gibbs free energy, is that it fully incorporates this influence. The Gibbs free energy of an ion pair in solution (e.g. $\mathrm{Ca}_{(\mathrm{aq})}^{2+}$ and $\mathrm{CO}_{3(\mathrm{aq})}^{2-}$ ) relative to its equilibrium position can be straightforwardly estimated from the ion activity product of the solution (Langmuir, 1997) with respect to a reaction. Throughout this study, the reaction of interest is the formation of solid calcite from solution $\left(\mathrm{Ca}_{(\mathrm{aq})}^{2+}+\mathrm{CO}_{3(\mathrm{aq})}^{2-} \mathrm{CaCO}_{3(\mathrm{aq})}\right)$. 
The calculation is performed via

$\Delta G_{\mathrm{r}}=\operatorname{RT} \ln \left(\gamma_{1}\left[\mathrm{Ca}_{(\mathrm{aq})}^{2+}\right] \gamma_{2}\left[\mathrm{CO}_{3(\mathrm{aq})}^{2-}\right] / K_{\mathrm{sp}}\right)$,

where $\Delta G_{\mathrm{r}}\left(\mathrm{kJ} \mathrm{mol}^{-1}\right)$ is the Gibbs free energy available in the solution relative to equilibrium, and therefore of the chemical potential that a spontaneous change in the system will occur. $R$ is the ideal gas constant $\left(8.314472 \times 10^{-3} \mathrm{~kJ} \mathrm{~K}^{-1} \mathrm{~mol}^{-1}\right), T$ is the temperature (in Kelvin), $\gamma_{1}$ and $\gamma_{2}$ are the activity coefficients for $\mathrm{Ca}_{(\mathrm{aq})}^{2+}$ and $\mathrm{CO}_{3(\mathrm{aq})}^{2-}$ respectively, squared brackets indicate concentrations (in moles). $K_{\mathrm{SP}}$ is the saturation product, given by Plummer and Busenberg (1982):

$K_{\text {sp }}=10^{\left\{-171.9065-(0.077993 T)+\left(\frac{2839.31}{T}\right)+\left(71.595\left(\log _{10} T\right)\right)\right\}}$.

Calculation of $\Delta G_{\mathrm{r}}$ could be achieved using a chemical model, such as PHREEQC. However, the use of different models, or indeed different generations of the same model, may cause differences in derived parameters such as $\Delta G_{\mathrm{r}}$. Moreover, different published works present different quantities of data regarding minor ions, making an approach based on model-based convergence of the solution charge balance partially dependent on the nature of the source. To circumvent these potential issues, here we estimate $\Delta G_{\mathrm{r}}$ values analytically. A key advantage of using this approach is that it makes the internal calculations underlying our approach explicit to any reader.

Activity coefficients $\gamma_{1}$ and $\gamma_{2}$ are calculated according to extensions of the empirical Davies model for ion activity (Langmuir, 1997):

$\log _{10} \gamma=-\mathrm{Az}_{i}^{2}\left(\frac{\sqrt{I}}{1+\sqrt{I}}-0.3 I\right)$,

where I is the ionic strength of the solution, A is a DebyeHückel parameter and $z_{\mathrm{i}}$ is ion charge.

$A=1.824928 \times 10^{6} \rho_{0}^{1 / 2}(\in T)^{-3 / 2}$,

where $\rho_{0}$ is the density of water and $\epsilon$ is the dielectric constant of water. Although it is dependent on temperature and salinity, here we use a constant value for $\rho_{0}$ for simplicity $\left(0.9997 \mathrm{~kg} \mathrm{dm}^{-3}\right)$. This is due to the uncertainty of calculating the density effects of the various potential solutions represented in our whole data set. This simplification is unlikely to cause any significant error in our analysis. The dielectric constant is calculated from Langmuir (1997):

$\epsilon=2727.586+0.6224107 T-466.9151 \ln T-52000.87 / T$.

An additional complication of using existing field data is that the typical $\mathrm{pH}$ range for terrestrial carbonate producing systems is from 8 to 9 , meaning that most dissolved inorganic carbon (DIC) is present as bicarbonate. This means in most cases $\left[\mathrm{CO}_{3}\right]_{(\mathrm{aq})}^{2-}$ must be estimated from the HendersonHasselbach-like control on the equilibrium constant of the second ionisation of DIC $\left(\mathrm{Ka}_{2}\right)$ exerted by the $\mathrm{pH}$, which varies with temperature and ionic strength (Patterson et al., 1984). An analytical means to determine these effects are available derived from the Debye-Hückel limiting law (see Appendix 1 for derivation):

$\left[\mathrm{CO}_{3}^{2-}\right]_{(\mathrm{aq})}=\mathrm{Ka}_{2}\left[\mathrm{HCO}_{3}^{-}\right]_{(\mathrm{aq})} 10^{3 A \sqrt{I}+p H}$.

Ultimately, we find that using this analytical approach, $\Delta G_{\mathrm{r}}$, can be calculated from field-derived measurements of temperature, $\mathrm{pH},\left[\mathrm{Ca}_{(\mathrm{aq})}^{2+}\right],\left[\mathrm{HCO}_{3(\mathrm{aq})}^{-}\right]$and ionic strength (i.e. the sum of all charge arising from dissolved ions), which is a data set that can be reasonably created for any new system. For systems with $\mathrm{pH}>10$, we use field-derived values for $\left[\mathrm{CO}_{3(\mathrm{aq})}^{2-}\right]$ instead as they can be accurately measured in these systems.

A potentially critically important, first-order parameter controlling the biological components the presence of which will affect the water-precipitate system is temperature. At high temperature (typically over $40^{\circ} \mathrm{C}$ ), macrophytes are excluded leaving only microbial processes to interact with mineral precipitation. At temperatures above $\sim 60^{\circ} \mathrm{C}$, biofilms will be dominated by thermophiles, diversity falls and the potential for biomediated precipitation will thus be altered.

We therefore propose that - to first-order - sites can be classified in a binary sense according to their $\Delta G_{\mathrm{r}}$ and water temperature, and that systems can be grouped according to whether they are high or low $\Delta G_{\mathrm{r}}$ versus high or low temperature. For the purposes of the classification proposed here we use temperature in degrees Celsius rather than degrees kelvin, which is used in forthcoming calculations. This is for the convenience of field scientists, who tend to measure using the former unit rather than the latter.

\subsection{Compilation of field data}

We do not pretend that the compilation of field data presented here is in any way comprehensive, and simultaneously recognise the advantage to future classification schemes if it were more comprehensive. We therefore link this paper to an online resource to which further data can be added, calculations are performed using a single set of equations and calculated parameters added to our database (https://hydra.hull.ac.uk/ resources/hull:7520). The field data used in the subsequent analyses are summarised in Table 2, which shows the wide range of compositions of near neutral-alkaline spring waters occurring in nature. To simplify these disparate data, a number of sub-populations are classified in terms of region of occurrence and water temperature (Table 2). Variance within these sub-populations remains quite high, with calcium concentration in cold Turkish springs varying by nearly $300 \%$ of the mean (Table 2). Ionic strength, which is only partially dependant on the position of a location relative to source, is the most constant; ionic strength in the water at Plitvice (Croatia) varies only by about $10 \%$ of the mean despite this being a 
Table 2. Summary of field data (SD, standard deviation).

\begin{tabular}{|c|c|c|c|c|c|c|c|c|c|}
\hline \multirow[t]{2}{*}{ Type of System } & \multicolumn{2}{|c|}{$\mathrm{T}\left({ }^{\circ} \mathrm{C}\right)$} & \multicolumn{2}{|c|}{$\mathrm{Ca}\left(\mathrm{mMol} \mathrm{L}^{-1}\right)$} & \multicolumn{2}{|c|}{$\mathrm{CO}_{3}\left(\mathrm{mMol} \mathrm{L}^{-1}\right)$} & \multicolumn{2}{|c|}{$\Delta G_{\mathrm{r}}\left(\mathrm{kJ} \mathrm{mol}^{-1}\right)$} & \multirow[t]{2}{*}{$n$} \\
\hline & Mean & SD & Mean & SD & Mean & SD & Mean & SD & \\
\hline Alkaline lake (Mono) & 8.5 & 2.8 & 0.05 & 0.02 & 218.3 & 233.3 & 16.37 & 6.71 & 29 \\
\hline Japanese spring & 13.6 & 3.6 & 1.6 & 0.8 & 0.01 & 0.009 & 0.25 & 5.81 & 13 \\
\hline Semi-arid temperate tufa river (Ruidera) & 13.0 & 9.9 & 1.6 & 0 & 0.005 & 0.002 & 1.53 & 0.26 & 2 \\
\hline Cool-humid temperate tufa river (Ddol) & 10.1 & 1.6 & 2.5 & 0.3 & 0.01 & 0.009 & 4.73 & 0.48 & 3 \\
\hline Cool Italian spring $\left(<20^{\circ} \mathrm{C}\right)$ & 11.7 & 2.4 & 2.5 & 1.8 & 0.004 & 0.004 & 0.40 & 2.19 & 63 \\
\hline Warm Italian spring $\left(20-30^{\circ} \mathrm{C}\right)$ & 24.3 & 2.9 & 10.1 & 3.4 & 0.006 & 0.005 & 2.48 & 1.61 & 22 \\
\hline Thermal Italian spring $\left(30-45^{\circ} \mathrm{C}\right)$ & 36.5 & 4.4 & 14.5 & 5.8 & 0.008 & 0.01 & 3.52 & 2.14 & 21 \\
\hline Hot Italian spring $\left(>45^{\circ} \mathrm{C}\right)$ & 53.5 & 5.5 & 15.6 & 3.3 & 0.01 & 0.01 & 5.14 & 2.31 & 13 \\
\hline Cool Turkish spring $\left(<20^{\circ} \mathrm{C}\right)$ & 26.1 & 13.2 & 1.0 & 2.9 & 17.8 & 25.3 & 10.92 & 3.70 & 43 \\
\hline Warm Turkish spring $\left(20-30^{\circ} \mathrm{C}\right)$ & 21.1 & 1.3 & 0.5 & 0.1 & 36.2 & 47.2 & 15.98 & 2.12 & 4 \\
\hline Thermal Turkish spring $\left(>30^{\circ} \mathrm{C}\right)$ & 42.0 & 3.0 & 2.1 & 5.8 & 15.5 & 12.4 & 17.55 & 8.59 & 6 \\
\hline Warm-humid temperature river (Plitvice) & 12.0 & 3.5 & 1.2 & 0.2 & 0.02 & 0.01 & 2.98 & 1.75 & 65 \\
\hline Hot silica spring & 88.3 & 20.8 & 0.6 & 1.2 & 0.9 & 1.4 & 6.19 & 3.04 & 4 \\
\hline
\end{tabular}

relatively large data set $(n=65)$. Even with the simplification provided by regional grouping, the data remain markedly unstructured in terms of the relationships between key parameters such as calcium and carbonate concentrations (Fig. 1a) or temperature and ionic strength (1b), all of which vary independently.

Comparison of water temperature and $\Delta G_{\mathrm{r}}$ (Fig. 2) does not result in more structure within the data, but it does result in better clustering of the data than individual ion concentrations, as sites can differ between very high carbonate ion but low calcium ion concentration (e.g. Mono Lake) and vice versa (many Italian springs). The thermodynamic approach therefore provides a suitable simplification of the data for further analysis.

\section{Towards linking process to product}

The first-order analysis of sites based on $\Delta G_{\mathrm{r}}$ versus temperature proposed above is shown in Fig. 3 (Fig. 3). There is a natural clustering of data in the region of the origin, reflecting the relatively high abundance of data from "meteogene" sources within karstic regions where deep crustal fluids are reaching the surface. Nevertheless, our collection of field data does encompass the majority of the $T-\Delta G_{\mathrm{r}}$ pace reasonable to expect from natural systems. We first report a case study from each quartile of the diagram, then highlight some key features of the transition zones between (e.g. between "hot" and "cold" systems) and on the edges (e.g. at the lower limit of significant carbonate production) of these quartiles.

We emphasise that we provide only basic descriptions of the sedimentary product for each class. Further reading is recommended for a case study in each case.

\section{1 "Hot, non-biomediated" systems with high temperature and $\Delta G_{\mathrm{r}}$}

We recommend that these systems are informally designated as "super travertine", and a full description of a representative system (Chemerkeu, Kenya) can be found in (Renaut and Jones, 1997). Water temperature at Chemerkeu is around $99^{\circ} \mathrm{C}$, and Gibbs free energy is around $8.76 \mathrm{~kJ} \mathrm{~mol}^{-1}$. A further example system of this type is Terme San Giovanni in Italy, where water temperature is $38^{\circ} \mathrm{C}$ and Gibbs free energy is $10.81 \mathrm{~kJ} \mathrm{~mol}^{-1}$.

In these systems, Gibbs free energy is high, providing significant chemical potential for mineralisation. Biota are restricted to thermophile microbes by high water temperature. Precipitation will be rapid and without material control from biological activity.

In high temperature thermal sites, calcium carbonate saturation levels are too extreme for extensive macrophytes or thermophile microbial biofilm development (Fig. 4). Such extreme hydrothermal waters equilibrate with surface conditions rapidly immediately upon resurgence, by cooling (increasing DIC solubility and altering chemical behaviour), ingassing (raising DIC), degassing (raising $\mathrm{pH}$ ) mixing with ambient waters (reducing ionic strength) or precipitating other minerals (reducing ionic strength). These processes can trigger very rapid precipitation of calcite which nucleates onto the substrate, which provides surfaces with reduced activation energy further promoting calcite precipitation (Fig. 4a, $\mathrm{d}, \mathrm{e}$ ). Such spontaneous crystalline precipitates are typically made up of palisade stands of sparite crystals with their Caxes oriented normal to substrate and with individuals from 1-60 mm long (Fig. 4c). These fabrics develop during rapid cooling and degassing associated with highly alkaline, flowing waters which are confined within small channels. The resulting botryoidal crystalline masses are composed of fanning crystal clusters, each crystal with it's own well formed 


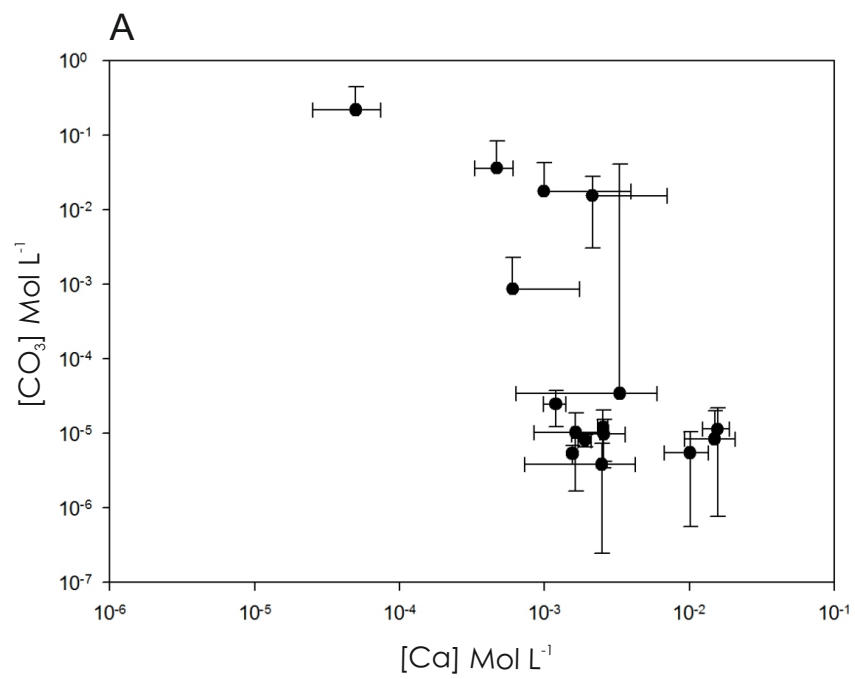

B

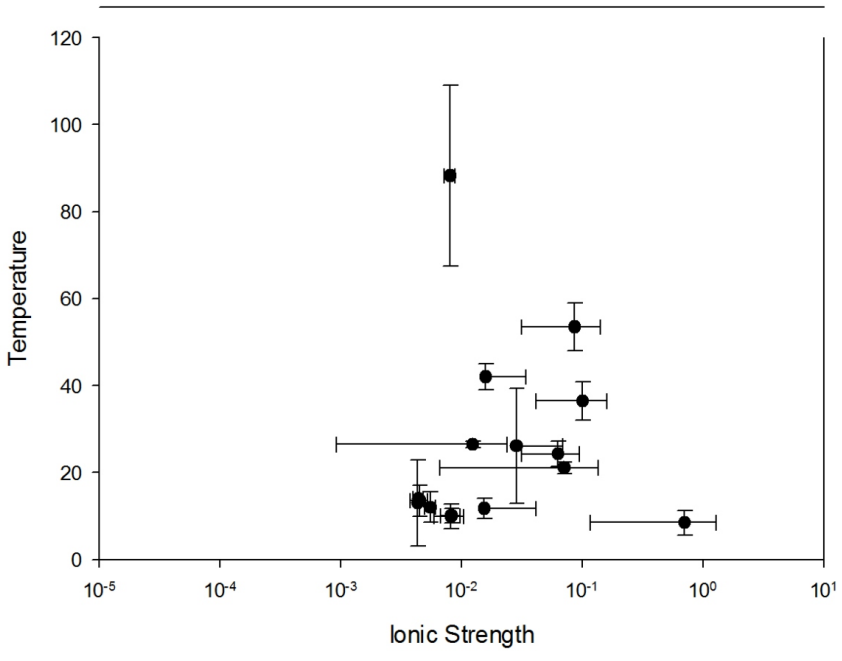

Figure 1. Summary of field data shown in Table 2 (note logarithmic scales). (A) Mean and standard deviation of calcium and carbonate concentrations in molarity. (B) Mean and standard deviation of temperature $\left({ }^{\circ} \mathrm{C}\right)$ and ionic strength (total electron volts $\left.\mathrm{dm}^{-3}\right)$.

crystal termination. These appear to be primary crystal fabrics, and are analogous to "columnar" fabrics described in speleothems growing in equilibrium with dripwater (Frisia et al., 2000). Clusters of calcite rosettes are also common. Crystal length appears to be controlled by water depth suggesting that standing pools best encourage this development. However, macroscopic rhombic calcite crystals also nucleate rapidly on the bottom of fast-flowing gutters to form complex fanning twins with overall botryoidal morphologies (Fig. 4b). When followed away from resurgence points these fabrics progressively give way to microbial dominated travertine and ultimately to ambient temperature paludal tufa laminites with dense macrophyte associations (Fig. 4d).

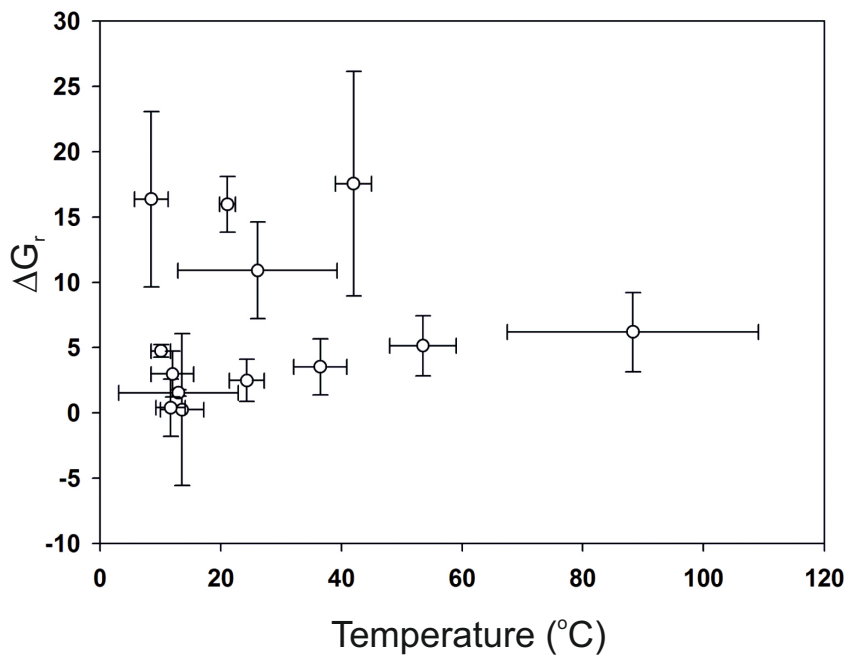

Figure 2. Summary of spontaneous nucleation index (dimensionless) and temperature $\left({ }^{\circ} \mathrm{C}\right.$ ) from Table 2 (note logarithmic scales).

\section{2 "Hot, biomediated" systems with high temperature and low $\Delta G_{t}$}

We recommend that these systems are informally described as "travertines", and the chemical, sedimentological and microbiological features of these systems are best described in Fouke et al., 2000 and 2003, and Veysey et al., 2008. At Angel Terrace, water temperature is around $73.3^{\circ} \mathrm{C}$ and Gibbs free energy is around $6.84 \mathrm{~kJ} \mathrm{~mol}^{-1}$.

This is the largest category of precipitates associated with hydrothermal processes. In these systems, Gibbs free energy is too low to allow rapid spontaneous nucleation, so that rapid precipitation is dependent on some mechanism allowing the activation energy to be reduced. At Angel Terrace, microbiological activity provides this additional mechanism (Fouke et al., 2000). However, biota can be restricted by high water temperature meaning that despite low Gibbs free energy, slow precipitation as a result of physical/chemical processes may still dominate. The possibility of "bioreactor" processes (Sect. 1.2.4) sustaining high microbial activity may be critical in determining whether precipitation is fast and bioinfluenced or slow and physico-chemical.

Deposits usually are confined to the immediate vicinity of the resurgence point and these may take the form of whaleback ridges (sublinear ridges often following fault lines), pinnacles and mounds. An apron of lower angle travertine sheets, with terracettes may also extend well beyond these constructions where flow rates are high (see details of Italian examples in Capezzuole and Gandin, 2005). Millimetre to centimetre thick laminae dominate all deposits and commonly are arranged into discrete bundles each separated by a truncation surface. These truncations may be karstified and buried by palaeosols indicating prolonged breaks in the depositional history. Individual laminae within bundles commonly show bubble, microlaminar and shrub fabrics (Fig. 5a, 


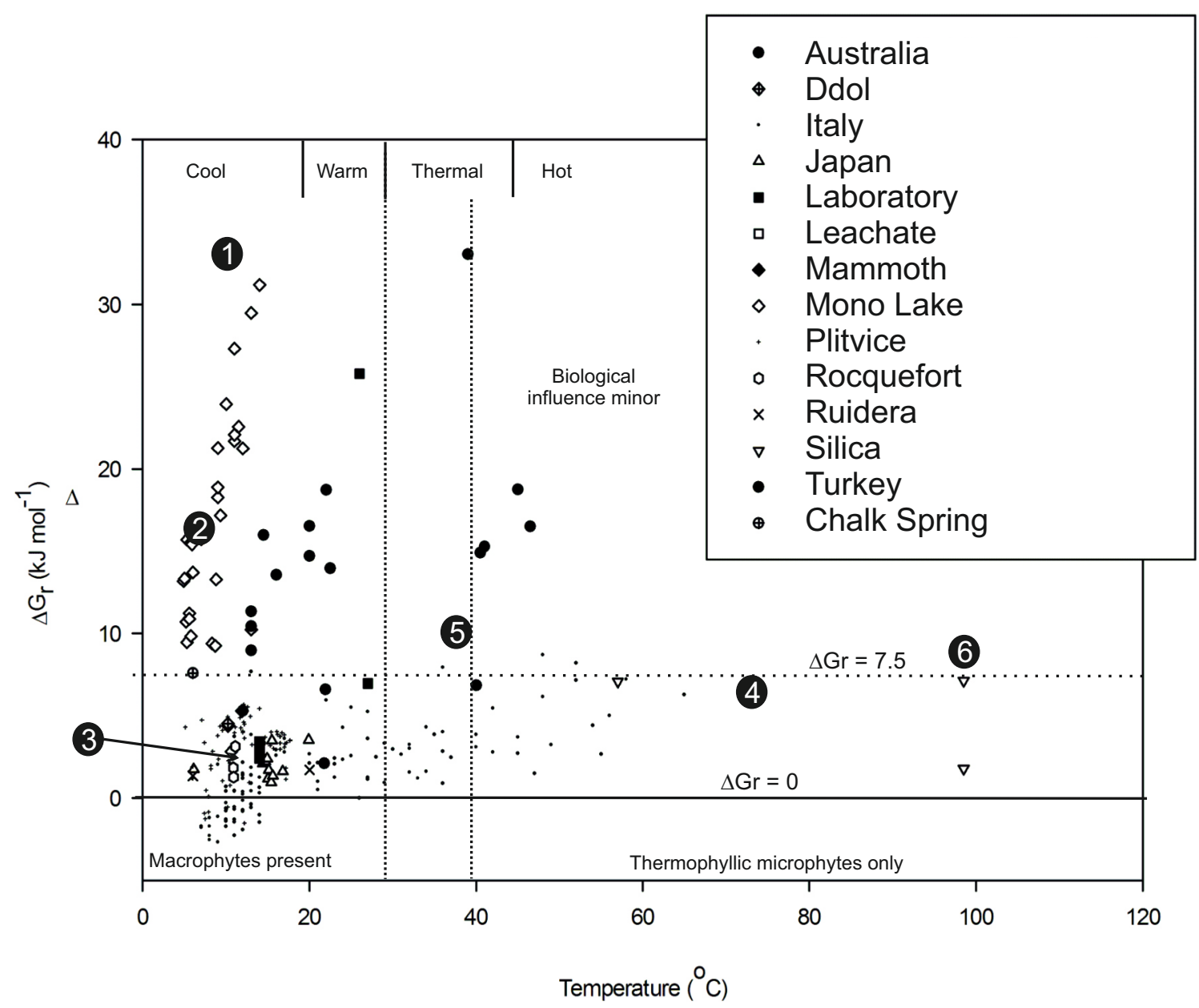

Figure 3. Summary of travertine and tufa spring water chemistries on thermodynamic grounds (see Sect. 3). 1: ,Brook Bottom (Sect. 3.3), 2: Mono Lake (Sect. 3.3), 3: Plitvice (Sect. 3.4), 4: Angel Terrace (Sect. 3.2), 5: Terme San Giovanni (Sect. 3.1), 6: Chemerkeu Spring (Sect. 3.1).

b, c). All macrophytes and many algae are excluded. Typically the deposits are extremely well cemented; the terracette laminae may show narrow rimstone pools and microgour topographies, whereas the faster flowing waters on steeper slopes (Fig. 5d) may create ripple developments.

\section{3 "Cold, non-biomediated" systems with low tempera- ture and high $\Delta G_{\mathrm{r}}$}

We recommend that these systems are informally described as "super tufa". Naturally occurring examples include Mono Lake (USA), and more complete information about facies distributions and stratigraphy can be found in Newton, 1994. At Mono Lake, water temperature is around $8.5^{\circ} \mathrm{C}$ and Gibbs free energy around $16.37 \mathrm{~kJ} \mathrm{~mol}^{-1}$. Anthropogenic examples, arising from hyperalkaline leachates from various industrial process by-products, are also frequent in the developed world. An example of this type of system is Brook Bottom in Derbyshire (UK), where water temperature is $10^{\circ} \mathrm{C}$ and Gibbs free energy is in the region of $33 \mathrm{~kJ} \mathrm{~mol}^{-1}$.

In these systems, the chemical potential represented by the high Gibbs free energy is sufficient for precipitation to happen readily. Biota may be abundant and diverse, but extreme composition of the water may also be limiting via toxicity. Regardless, abiotic mineral precipitation is dominant and sufficiently rapid for biological influence to be minor and therefore masked in resulting deposits. As well as natural systems, such as Mono Lake (USA), systems of this type occur abundantly where leachate from alkaline waste (from lime, steel, chromium, alumina and other industries) in landfill reaches the surface. These anthropogenic "super tufa" systems are potentially significant sinks for carbon, in addition to being important environmental hazards due to their extreme chemical composition (Mayes et al., 2008).

Extremely high alkalinity in these environments leads to continuous, pelagic lime mud precipitation which often results in a milky to pale turquoise colour to the water even 

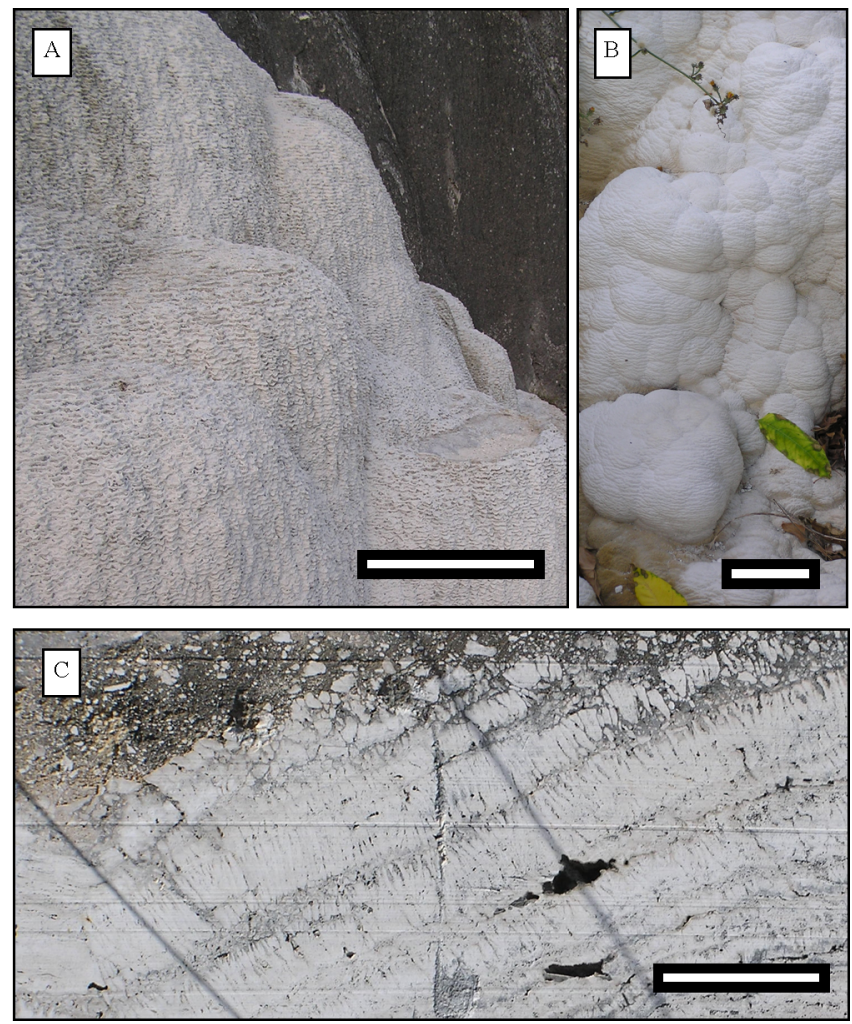

Figure 4. High temperature and $\Delta G_{\mathrm{r}}$. (A) Travertine build-up at the outflow point from the spar pool. Steep gradient microterracettes are typical of the deposit. Scale bar is $1 \mathrm{~m}$ long. Terme San Giovanni, Tuscany, Italy. (B) Crystalline calcium carbonate in botryoidal masses lining an outflow channel. Scale bar is $100 \mathrm{~mm}$ long. Terme San Giovanni, Tuscany, Italy. (C) Palisade calcite growing normal to substrate within a Holocene travertine site. The sequence is capped by a palaeosol. Scale bar is $300 \mathrm{~mm}$ long. Terme San Giovanni, Tuscany, Italy.

during cooler periods (Fig. 6). Aquatic organisms are generally excluded from such waters due to the extremely high precipitation rates which choke gill-breathing organisms and deeply encrust vegetation in precipitates after only a few hours.

The water itself may not be toxic, however, and extensive marginal vegetation may develop throughout the system (Pedley, 2000). Biofilms are thin and discontinuous and mainly located on the narrow spill-over points of rimstone pools in the paludal areas and in broader botryoidal areas of barrage growth across the outflowing watercourses (Fig. 6a). Precipitates are rapid with extensive development of rimstone pools each forming broad terracettes separated by narrow sinuous crested microdams. Pool depths in the paludal areas are generally a few centimetres deep and are infilled with lime muds (Fig. 6b, c). These muds are generated by precipitation within the pool areas and may be massive or finely laminated. Lithification generally is absent in the pool deposits and only weak within the rimstone dam areas. At
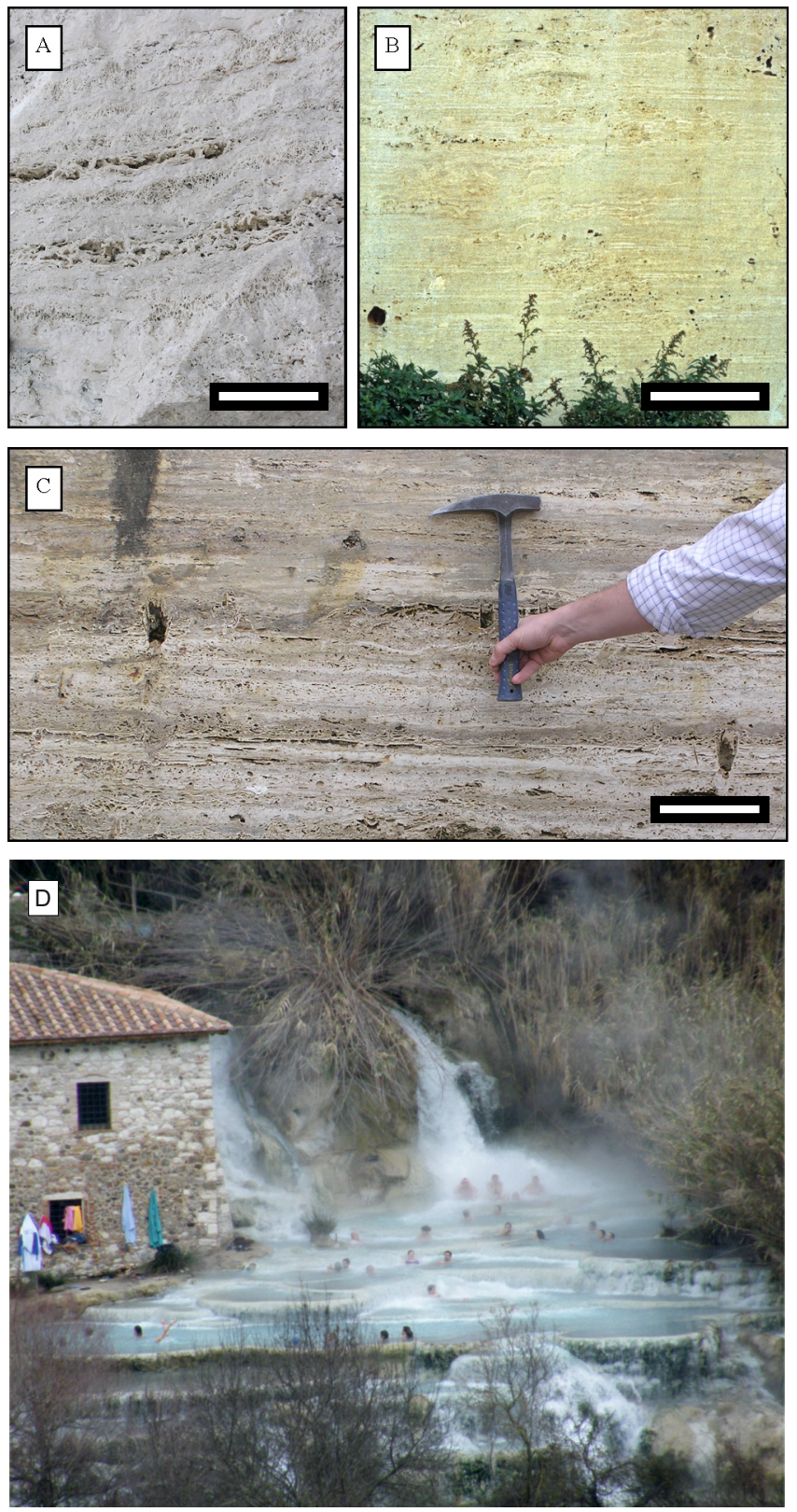

Figure 5. High temperature, low $\Delta G_{\mathrm{r}}$. (A) Laminated travertine with alternating bubble and laminate layering. Scale bar is $50 \mathrm{~mm}$ long. Holocene, Cava Oliviera, Tuscany, Italy. (B) Laminite-filled pools bounded by bacterial microherm dominated pool rims. Scale bar is $150 \mathrm{~mm}$ long. Early Quaternary Alcamo travertine, Sicily, Italy. (C) Typical laminated microbial travertine fabric. Scale bar is $150 \mathrm{~mm}$ long. Holocene Cava Oliviera, Tuscany, Italy. (D) Typical rim pool system from Saturnia, Tuscany, Italy. Note swimmers for scale, and steam rising from warm water (with thanks to Enrico Cappezuoli).

faster flowing sites, small transverse barrages of weakly lithified lime mud laminites develop into broad, vertical to overhanging botryoidal walls which impound small, deep pools floored with unlithified lime muds. These muds are typi- 

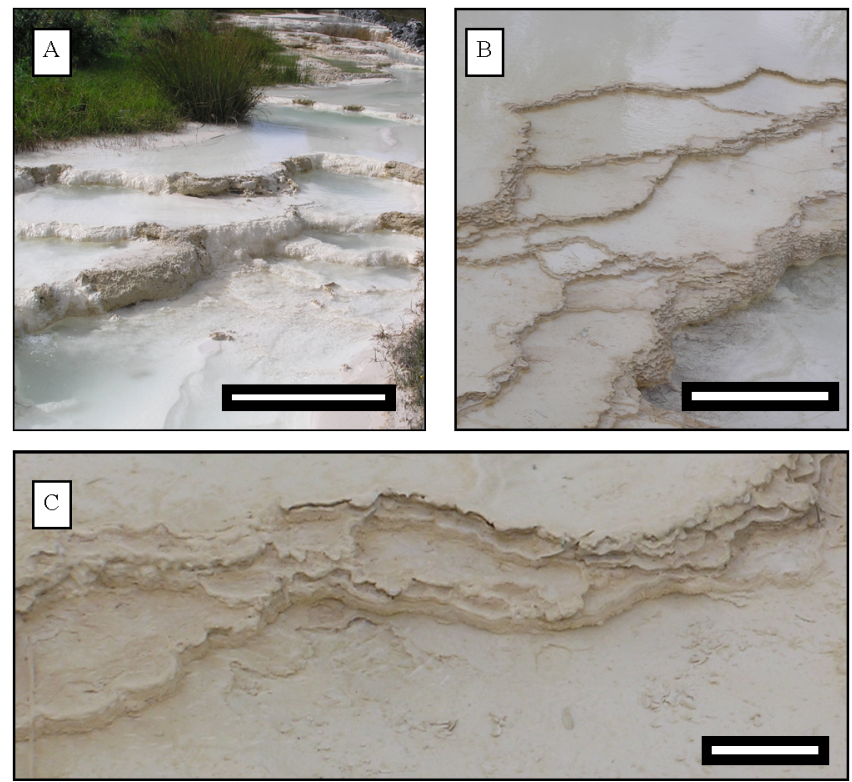

Figure 6. Low temperature, high $\Delta G_{\mathrm{r}}$. (A) Terrace and pool morphology in an active ambient temperature deposit. Note the large volume of lime mud within the pools. Scale bar is $1 \mathrm{~m}$ long. Brook Bottom, near Buxton, Derbyshire, UK. (B) Detail of the terracettes developed in gentle gradient sites. Note how the large upstream pools progressively overstep the smaller downstream features and progressively encourage the development of steps. Scale bar is $0.5 \mathrm{~m}$ long. Active, Brook Bottom, near Buxton, Derbyshire, UK. (C) Fine detail of the narrow pool rims and spillovers. Scale bar is $100 \mathrm{~mm}$ long. Brook Bottom, near Buxton, Derbyshire, UK.

fied by bizarre, microcrystalline calcite growthforms with abundant imperfectly formed crystals, some with baroque faces, by hollow microspheres and by truncated skeletal crystal growthforms. Tufa towers may grow under similar conditions within alkaline lakes (e.g. Mono Lake, USA). These vertical structures also exhibit rapid growth fabrics with occasional microbial laminations, but are essentially inorganic carbonate precipitates.

\section{4 "Cold, biomediated" systems with low temperature and $\Delta G_{\mathrm{r}}$}

We recommend that these systems are informally described as "tufa", and the most widely used facies model for cold, biomediated terrestrial carbonate systems is Pedley (1990). An excellent example of this type of system is Plitvice (Croatia) where water temperature is on average $12.04{ }^{\circ} \mathrm{C}$, and Gibbs free energy is $2.98 \mathrm{~kJ} \mathrm{~mol}^{-1}$.

These are the classic, karstic tufa systems and are the most widespread form of terrestrial carbonate from spring, fluvial, lacustrine and paludal settings (Ford and Pedley, 1996). The Gibbs free energy is too low to allow rapid spontaneous mineral formation, so that precipitation is dependent on some mechanisms allowing the activation energy to be reduced.
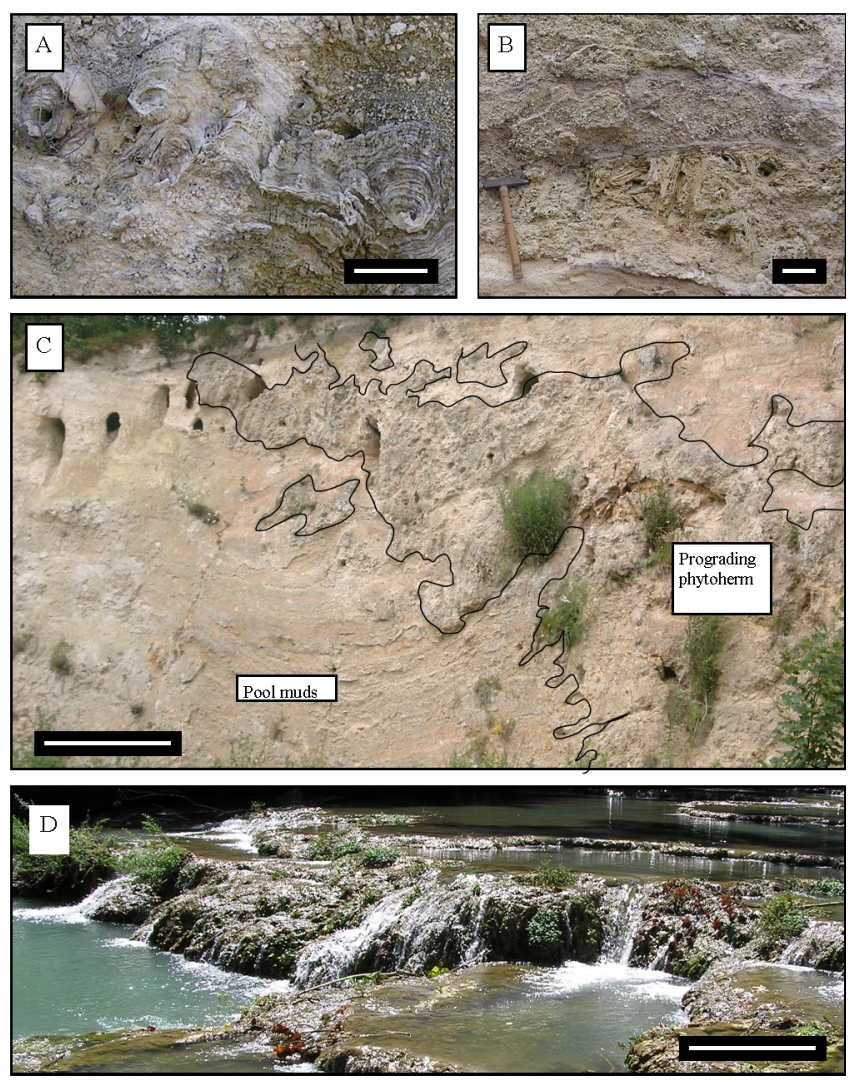

Figure 7. Low temperature, low $\Delta G_{\mathrm{r}}$. (A) Stromatolite microherm development in a fluvial tufa. Scale bar is $50 \mathrm{~mm}$ long. Early Quaternary Noto tufa, Sicily, Italy. (B) Burr reed Phytoherm cushion interlayered with detrital tufas above and lacustrine lime muds below. Scale bar is $150 \mathrm{~mm}$ long. Holocene Caerwys tufa, North Wales. (C) Profile view of a prograding phytoherm framestone sandwiched between adjacent lime mud pool deposits. Scale bar is $150 \mathrm{~mm}$ long. Holocene Caerwys tufa, North Wales. (D) An active pool and barrage system forming in Tuscany (cf. 2C). Scale bar is $1 \mathrm{~m}$ long. Colle val d'Elsa, Italy.

Biota are abundant and diverse, permitting the full range of biomediation mechanisms to be active.

These deposits (Fig. 7) are extensively developed in association with phytoherm framestones in fluviatile perched springline, paludal and lacustrine settings (Pedley, 1990). Biofilms are developed on all available surfaces and all actively precipitate thick calcium carbonate laminae, often composed of alternations of spar and micrite cements and commonly developed into stromatolitic growths (Fig. 7a). Micritic precipitates with a characteristic laminar or peloidal texture may also dominate the system (Fig. 7b, c). A diverse range of invertebrates, vertebrates and vegetation are always associated with these sites. Precipitates rapidly lithify and progressively entomb earlier biomediated areas. Typically, they agrade and prograde into lithofacies-scale deposits (Fig. 7c) which bury macrophytes and are capable of infilling valleys. These impound bodies of water from pond to lake 
scale (Fig. 7d) within which further pelagic precipitation occurs and regularly laminated lake floor lime muds accumulate which may be associated with sapropels.

\subsection{Interfacial systems with temperature in the region of $30-40{ }^{\circ} \mathrm{C}$.}

These deposits show overlapping similarities with travertine and tufa systems, and are likely to show interfingering of facies stratigraphically at individual sites. The most important impact of this in terms of product is that aquatic macrophytes are likely to be excluded by the high temperature, but may periodically establish when/where their physiological temperature threshold (ca. $30^{\circ} \mathrm{C}$ ) is reached. Microbiota may be abundant and diverse depending on local ecological factors, but the composition of biofilms will differ from systems developing at lower temperatures. Diatoms grow best at temperatures $<35^{\circ} \mathrm{C}$ and photosynthetic elements of biofilms above this temperature will be dominated by cyanobacteria (Blanchard et al., 1996) meaning that the metabolic functioning of biofilms will alter through the $30-40{ }^{\circ} \mathrm{C}$ temperature range.

These deposits manifest in an abundance of thermophile and ambient temperature microbial colonisers associated with scattered, small cushion-shaped phytoherms (often single species of grass) throughout (Fig. 4a, b). There is also a marked tendency for laminite development, partially arising from the flow conditions of these sites which are typically found on the outermost gently inclined parts of travertine sheets and distal margins of thermal fissures (Fig. 4a). Here, the virtually ambient temperature of the outflowing formerhydrothermal waters is sufficiently low to permit scattered macrophyte colonisation. Figure $4 \mathrm{~b}$ shows a profile view of the colonisers in the Cava Oliviera quarry. Note the nonpreservation of roots and the thick accumulation of laminites around the vegetation. In some instances over $100 \mathrm{~mm}$ of laminate accumulation has occurred during the lifetime of individual plants, which attests to high nucleation rates in these cases.

\subsection{Interfacial systems with moderate $\Delta G_{\mathrm{r}}$}

In close analogy with temperature, systems which are marginal in terms of $\Delta G_{\mathrm{r}}$ will present mixed petrologies and geomorphologies from the high and low $\Delta G_{\mathrm{r}}$ type systems. Again in close analogy with high temperature systems, high $\Delta G_{\mathrm{r}}$ systems will inevitably evolve into low $\Delta G_{\mathrm{r}}$ systems in time and space. However, the $\Delta G_{\mathrm{r}}$ range this transition will occur at is not well determined by our data, due to lack of specifically collected field petrographic evidence, beyond a general indication it will lie at $\Delta G_{\mathrm{r}} \sim 7.5 \mathrm{~kJ} \mathrm{~mol}^{-1}$. This transition is an interesting target for future field research.

In terms of product, biomediated and physico-chemical type products will interfinger both in time and space in these interfacial systems, in the same manner that high and low

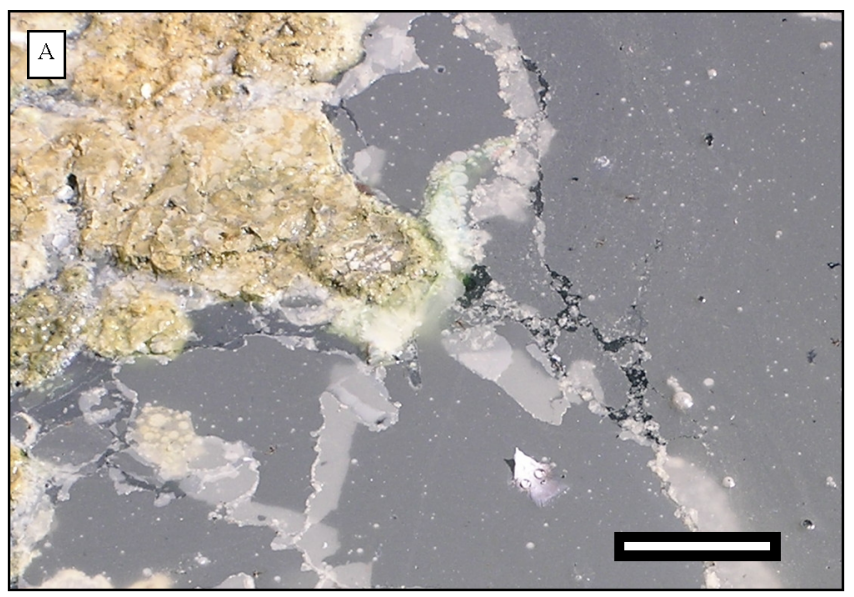

Figure 8. Marginally precipitating systems under high temperature. Living biofilm associated with superficial skins of calcite. Note the thin calcite rafts at the air-water interface. This is the only observable precipitate at the site. Scale bar is $100 \mathrm{~mm}$ long. Recent, Petreole, Tuscany.

temperature products interfinger in time and space in thermal interfacial systems. Again, there is a lack of field data concerning the diagnosis of these hydrochemical transition zones.

\subsection{Defining the hydrochemical lower boundary of ter- restrial carbonate precipitation}

In these marginal systems where there is insufficient Gibbs free energy for calcite to nucleate spontaneously, precipitation will largely if not exclusively be biomediated. Consequently, at high temperatures where waters are too hot for macrophyte colonisation (although they may be extensively colonised by thermophilic microbial mats) and thus biomediation is limited, significant precipitates and petrographic data are sparse. Any carbonate precipitates will be thin and slow to develop. Typically, thin calcite rafts floating on the surface of resurgence pools are the only tangible precipitates (Fig. 8). Progressively as the precipitate slowly develops these rafts become too heavy to be held on the meniscus and they sink to produce chaotic pseudo-floe calcite sheet debris.

At low temperature, an extensive development of biofilm will coat available substrates (Fig. 9a, b). However, precipitates will tend to be restricted to thin, micritic laminae within the EPS discontinuous on the sub-metre scale. Generally, in cooler humid climatic situations these developments are localised to resurgence points, the resurgences sometimes being identified by a very restricted patch of thin tufas in its immediate vicinity (Fig. 9c). Commonly the carbonate precipitates are not visible in the field, but can be viewed by binocular microscope as whitish films or particulate micrite on and within the biofilm surface. A diverse range of biota is associated with these sites. A common type of development in the 

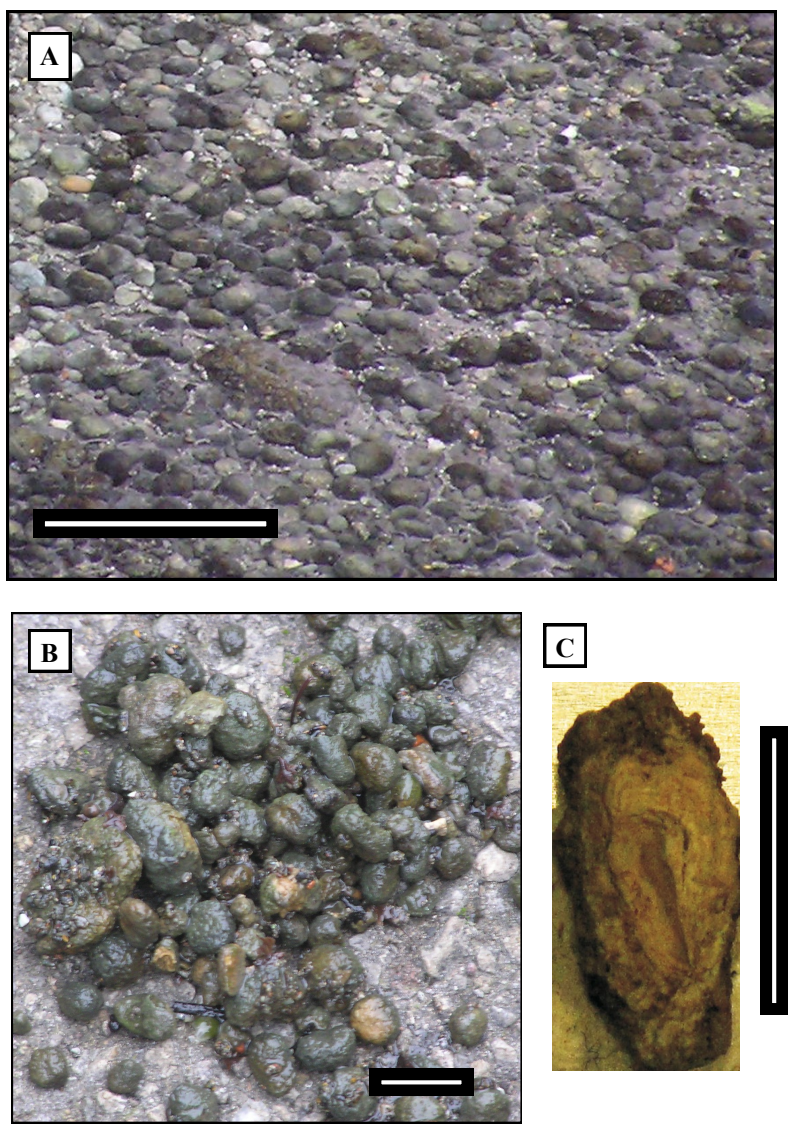

Figure 9. Marginally precipitating systems under low temperature. (A) Sub-tufa oncoids in a flowing, shallow stream without any framework tufa associations. These typically build climbing ripple bedforms. Scale bar is $150 \mathrm{~mm}$ long. Welton Beck, Yorkshire, UK. (B) Close up of a random sample of living oncoids showing characteristic greyish green colour. Note the virtual absence of any detrital tufa or cements between the oncoids. Scale bar is $15 \mathrm{~mm}$ long. Welton Beck, Yorkshire, UK. (C) Oncoid in cross section from River Bradford, Derbyshire, UK. Note colonised surface (left and top) is not continuous, and laminae are apparent (e.g. light coloured middle section) but these are discontinuous on the scale of a few millimetres. Dark core material (centre) is a flake-shaped piece of carboniferous limestone. Scale bar is $50 \mathrm{~mm}$ long.

Yorkshire dales and in Belgium is associated with "Cron"type sites (Pentecost, 2005) where discontinuous biofilms develop in the capillary zone on the surface of grass or moss cushions. The micrite precipitates may lithify into thin delicate sheets or may constantly wash or fall from these vertical surfaces and develop into peripheral, detrital lime mud deposits. In flowing waters there is a common tendency for marginal systems to be associated with thin calcite films precipitated in association with epiphyllous algae on the under surface of river weed such as Potamogeton.

Thinly encrusted oncoids in which a few thin skins of carbonate are wrapped around suitable sized clastic nuclei are another common association of sub-tufa environments
(Fig. 9a, b). Continental carbonate oncoids are laminated, microbially precipitated, millimetre to centimetre diameter spheroids which grow under turbulent conditions at the sediment-water interface and have laminae constructed of sparitic, thrombolitic or micritic carbonate, or an alternation of more than one of these. Although oncoids were originally described from the marine realm (Peryt, 1983; Riding, 1991) they are also common in ambient (Pedley, 1990, 2009) and thermal freshwater (Chafetz and Guidry, 2003; Jones et al., 1998) situations and can routinely be found in fossil terrestrial carbonate deposits (Fig. 9b).

However, we do not find that it is possible to draw a horizontal line in Fig. 3 dividing sites precipitating significant and insignificant carbonate. This echos a previous assessment of surface water in the Yorkshire Dales (UK), where no spatial relationship between water chemistry and precipitate occurrence could be identified (Pentecost, 1992) and other efforts in which precipitation was simultaneously present and absent in hydrochemically similar sites (Hagele et al., 2006; Ledger et al., 2008). Thus, we do not find the failure of thermodynamics to determine this boundary a surprising result, as $\Delta G_{\mathrm{r}}$ decreases and biomediation becomes more important to carbonate creation, small-scale variations in $\Delta G_{\mathrm{r}}$ will inevitably become immaterial. Clearly another direction is needed to determine this boundary.

\section{Towards a new paradigm for defining the lower limit on carbonate precipitation at low $\Delta G_{\mathrm{r}}$}

As biofilms play a demonstrable role in promoting calcite precipitation (Bissett et al., 2008a; Shiraishi et al., 2008a, b; Pedley et al., 2009; Rogerson et al., 2008) and typically demonstrate a tendency to alter the macroenvironment rather than be altered by it (Rogerson et al., 2010; Bissett et al., $2008 \mathrm{~b}$ ) it is likely that a new paradigm for the process determining the lower limit of terrestrial carbonate precipitation will arise from better understanding of microbial processes. This will require a fundamental reassessment of how fieldwork in these systems is performed, as even rather basic microbiological information is very seldom collected for terrestrial carbonate systems. Using a case study from Lincolnshire (UK) (Fig. 10), we propose a potential way forward.

\subsection{Lincolnshire case study; demonstrating the coinci- dence of high microbial activity and precipitation of significant carbonate in "borderline" systems}

In this case study, we emphasise the failure of thermodynamic assessments to determine the lower boundary of significant terrestrial carbonate production, and simultaneously attempt to link that boundary to a relatively simple assessment of on-site microbial activity. Although probably not significant players in biomediation of precipitate, local maxima in the suspended bacterial count will reflect locally enhanced productivity. This close association of higher biomass and 


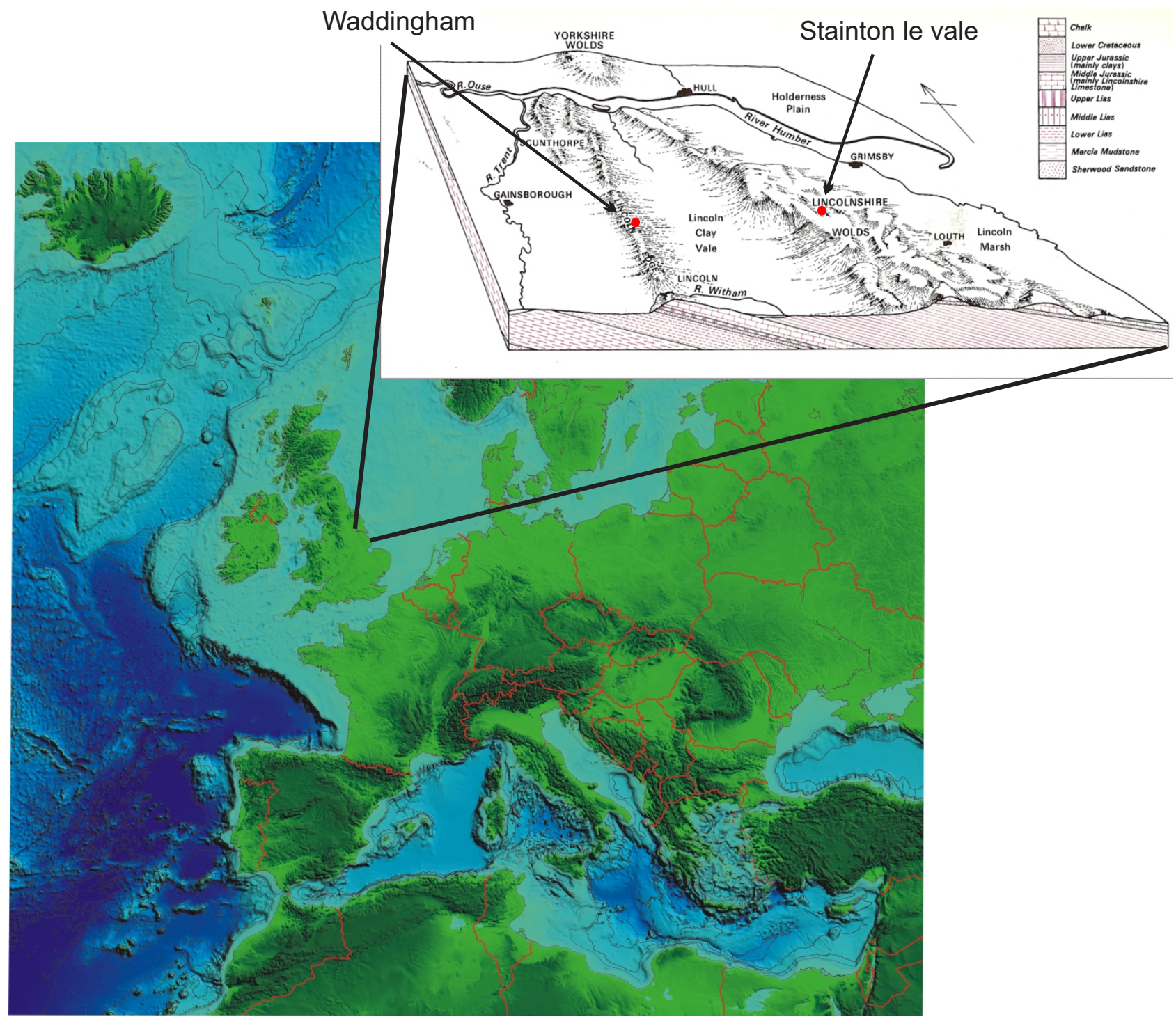

Figure 10. Location of tufa and sub-tufa sites in Lincolnshire, UK. Insert: geological map from Kent et al. (1980).

diversity at tufa sites relative to non-tufa sites is not our suggestion, but a known feature of these systems (Marks et al., 2006). To incorporate a simple microbiological measurement to the classification framework we propose here, we use suspended bacterial count as a proxy for the ecological energy flux (Marks et al., 2006) in the same way that water chemistry measurements traditionally act as a proxy for the gradient of thermodynamic forcing (see Sect. 2).

\subsubsection{Background information on sites}

The annual rainfall in Lincolnshire is $577 \mathrm{~mm}$, and average summer and winter air temperatures are 18 and $5{ }^{\circ} \mathrm{C}$ respectively. The first location, Stainton le Vale (UK grid reference TF17622 BNG93804; Fig. 10), lies on the Cretaceous chalk Wold hills and aquifer water emerges from two springs po- sitioned a few metres apart at the base of a quartzarenite bed that occurs within the chalk. Limited carbonate precipitation occurs along the stream banks and onto the biofilmencrusted carbonate surfaces of a small ( $1.5 \mathrm{~m}$ high) tufa cascade (Fig. 11). Three sites have been studied from this valley: $\mathrm{S} 1$ is upstream near the springs where there is no geomorphologically significant carbonate forming, $\mathrm{S} 2$ is adjacent to the waterfall where crystalline patches of older carbonate outcrop at the water surface-stream bank interface but is barely producing a significant "tufa" product, S3 is downstream where the stream emerges from woods and flows through cultivated land, and no deposition is evident. The second location is at Waddingham, which lies on the eastern side of the Lincolnshire Edge, Jurassic limestone hills (UK grid Reference SK96457 BNG95311; Fig. 10). Again three sites were studied, one of which shows only oncoid development (W2) 

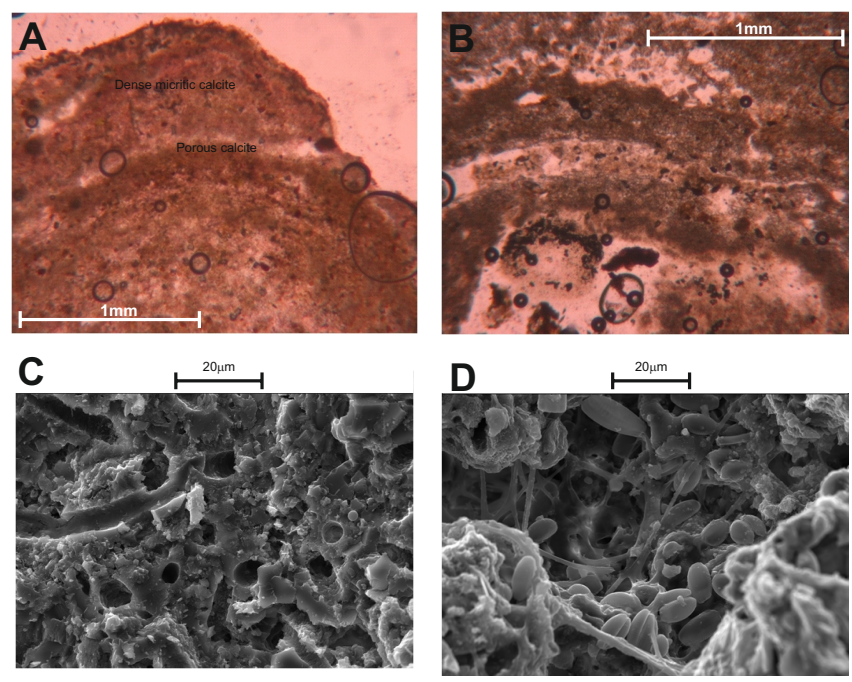

Figure 11. Photomicrographs of tufa deposit from Stainton, Lincolnshire, UK. (A) and (B) transmitted-light images showing alternative layers of micrite and porous calcite. (C) SEM image showing tubular holes in calcite left by loss of cyanobacterial filaments. (D) clotted calcite bodies with cyanobacterial filaments and diatoms in the centre of the view.

and two which are respectively immediately upstream and immediately downstream of the oncoid site (W1 and W3) and produce no significant precipitation.

The precipitate at site $\mathrm{S} 2$ is a friable, porous deposit adhering to the outer surface of siliciclastic stream bank muds. The precipitate is closely associated with organic matter, moss, fungi, heterotrophic bacteria and cyanobacteria from stream waters and surrounding vegetation. Microscopic grains cemented into the carbonate fabric enable smallscale aggradational seasonal laminae to be seen (Fig. 11). The sheet-like morphology of both precipitate and biofilm laminae consist of alternative clotted micrite and spar calcite. The degree of lithification, scarcity of detrital grains and association with organic components together identify this deposit as a tufa according to the terminology first proposed by Pedley (1994).

\subsubsection{What makes the tufa site "Stainton 2" (S2) different from the other non-product producing sites (S1, S3 and $\mathrm{W} 1-3)$ ?}

Counter-intuitively, calcium (mean $=130 \mathrm{mg} \mathrm{L}^{-1}$; Table 3) and bicarbonate (mean $=168.5 \mathrm{mg} \mathrm{L}^{-1}$; Table 3 ) concentrations are all higher at the Waddingham oncoid site than at Stainton (78.5 $\mathrm{mg} \mathrm{L}^{-1}$ and up to $93.5 \mathrm{mg} \mathrm{L}^{-1}$; Table 3), possibly reflecting the source water being derived from friable limestone rather than the less solution-prone, well-lithified chalk. Both systems have $\mathrm{pH}$ in the range 7.5-8.3, and magnesium concentrations are of the same order of magnitude (Table 3) . It is therefore completely unsustainable to assume the tufa-sub-tufa boundary is controlled by the thermody- namic forcing of source waters; the simple water chemistry approach we otherwise advocate in this paper would indicate that Waddingham was more likely to be above the tufa to sub-tufa boundary than is Stainton. There must, therefore, be another mechanism dominating these systems which is not reflected within the water analyses.

The difference between Stainton and Waddingham must therefore arise from microbiological effects. Suspended bacterial abundance (Table 3; established via a simple cellcounting procedure (Hobbie et al., 1977) where cells in $50 \mathrm{ml}$ of formaldehyde-fixed water were stained with Acridine orange, drawn through a filter membrane with $0.22 \mu \mathrm{m}$ pore size and counted under an epifluorescent microscope) strongly differs between the $\mathrm{S} 2$ site where tufa is forming (22 617 cells $\mathrm{mL}^{-1}$ ) and both other sites at Stainton (3490 and 3134 cells $\mathrm{mL}^{-1}$ for $\mathrm{S} 1$ and $\mathrm{S} 3$, respectively) and all locations at Waddingham $\left(1325,1228\right.$ and 1131 cells $\mathrm{mL}^{-1}$ respectively for stations $\mathrm{W} 1-\mathrm{W} 3$ ).

Although we do not know if these suspended cells themselves are inducing precipitation, it is likely that they at least reflect a more diverse and abundant benthic ecology at the S2 site than at any of the other sites studied in this case study. The difference in microbiological activity at sites precipitating significant calcite and those not doing so has previously been reported (Hagele et al., 2006; Marks et al., 2006; Ledger et al., 2008), but requires significant, further field-based research before it is understood at the fundamental biogeochemical level. A fundamental reassessment of well-known systems is therefore required, and testing the concept that suspended cells can be used as a proxy for enhanced biologically induced (Lowenstam, 1981) precipitation may be a fruitful initial avenue to explore.

\section{Conclusions}

Binary analysis of $\Delta G_{\mathrm{r}}$ and water temperature of terrestrial carbonate-producing systems appears to be a fruitful avenue to pursue with the goal of a single, unified process-oriented classification of these systems in mind. Both parameters are material to regulating whether biological influences are key in the precipitation process. As understanding past precipitation environments are critically dependent on establishing whether precipitation was via metalorganic intermediaries or direct from solution, determining which quartile of temperature $-\Delta G_{\mathrm{r}}$ space a precipitate reflects will underpin all subsequent investigation of that material and its environmental significance.

We do not currently have the information available to determine the $\Delta G_{\mathrm{r}}$ level at which non-biological precipitation begins to dominate, other than that this level appears to be in the region of 7.5. This is likely to be a fruitful avenue of research to pursue. Once this level has been determined, it will be possible to identify the dominant precipitation mechanics occurring in whichever specific system is being studied 
Table 3. Mean field data for sites at Stainton and Waddingham, Lincolnshire, UK.

\begin{tabular}{|c|c|c|c|c|c|c|c|c|c|c|c|c|c|}
\hline Location & $\mathrm{pH}$ & $\begin{array}{l}\text { water } \\
\text { temp } \\
\left({ }^{\circ} \mathrm{C}\right)\end{array}$ & $\begin{array}{r}\text { air } \\
\text { temp. } \\
\left({ }^{\circ} \mathrm{C}\right)\end{array}$ & $\begin{array}{r}\text { humidity } \\
\%\end{array}$ & $\begin{array}{r}\text { flow } \\
\text { rate } \\
\mathrm{m} \mathrm{s}^{-1}\end{array}$ & $\begin{array}{r}\mathrm{Ca} \\
\mathrm{mg} \mathrm{L}^{-1}\end{array}$ & $\begin{array}{r}\mathrm{Mg} \\
\mathrm{mg} \mathrm{L}{ }^{-1}\end{array}$ & $\begin{array}{l}\mathrm{HCO}_{3}^{-} \\
\mathrm{mg} \mathrm{L}^{-1}\end{array}$ & $\begin{array}{c}\mathrm{CO}_{3}^{2-} \\
\mathrm{mg} \mathrm{L}^{-1}\end{array}$ & $\begin{array}{r}\mathrm{NO}_{3}^{-} \\
\mathrm{mg} \mathrm{L}^{-1}\end{array}$ & $\begin{array}{c}\mathrm{PO}_{4}^{3-} \\
\mathrm{mg} \mathrm{L}^{-1}\end{array}$ & $\begin{array}{r}\text { DOC } \\
\mathrm{mg} \mathrm{L}^{-1}\end{array}$ & $\begin{array}{c}\text { Cell } \\
\text { count } \\
\text { per } \mathrm{mL}\end{array}$ \\
\hline Waddingham 1 & 8.1 & 10.3 & 10.7 & 76.5 & 0.2 & 140.4 & 1.4 & 172.8 & 12.5 & $<10$ & 1.7 & 5.5 & 1325 \\
\hline Waddingham 2 & 8.1 & 10.3 & 11.9 & 73.5 & 0.3 & 130.0 & 1.8 & 168.5 & 17.7 & $<10$ & 0.7 & 5.6 & 1228 \\
\hline Waddingham 3 & 7.8 & 10.4 & 12.3 & 73.9 & 0.4 & 117.5 & 1.2 & 170.3 & 7.8 & $<0$ & 2.0 & 5.9 & 1131 \\
\hline Stainton 1 & 7.7 & 9.5 & 11.6 & 72.3 & 0.4 & 80.6 & 5.7 & 91.5 & 0 & $<0$ & 1.8 & 7.3 & 3490 \\
\hline Stainton 2 & 8.0 & 9.5 & 11.5 & 76.6 & 0.3 & 78.5 & 3.6 & 93.5 & 7.7 & $<0$ & 1.0 & 7.3 & 22617 \\
\hline Stainton 3 & 8.1 & 9.5 & 11.7 & 76.6 & 0.3 & 73.0 & 3.3 & 93.5 & 10 & $<0$ & 1.9 & 6.8 & 3134 \\
\hline
\end{tabular}

allowing much more sophisticated analysis of process. For fossil systems, this will also allow us to determine whether a specific product indicates conditions above or below this critical value.

We also do not have the information available to understand the lower limit of $\Delta G_{\mathrm{r}}$ at which significant precipitation takes place. Indeed, we find it is unlikely any such division can be determined, but that precipitation dynamics at this level is regulated by biology rather than purely physical processes. We emphasise this problem with a new case study. We also propose a simple field-based means of further investigation of the role of biology in regulating this system, and show that at sites of precipitation suspended cell count is up to an order of magnitude higher than adjacent reaches of the same river. This is also likely to be a fruitful avenue for future research.

\section{Supplementary material related to this article is available online at http://www.earth-surf-dynam.net/2/ 197/2014/esurf-2-197-2014-supplement.zip.}

Acknowledgements. We sincerely thank the many field workers, without whose published data this contribution would have been impossible. We also thank John Adams for his help with suspended cell count measurements. Associate editor Edward Tipper is warmly thanked for his careful and tolerant editing of this submission, and the reviewers Alex Brasier, Adrian Immenhauser and Nick Tosca for their very significant contributions, which immeasurably improved our work.

Edited by: E. Tipper

\section{References}

Anadon, P., Utrilla, R., and Vazquez, A.: Mineralogy and Sr-Mg geochemistry of charophyte carbonates: a new tool for paleolimnological research, Earth Planet. Sci. Lett., 197, 205-214, 2002.

Andrews, J. E.: Palaeoclimatic records from stable isotopes in riverine tufas: Synthesis and review, Earth-Science Reviews, 75, 85104, 2006
Andrews, J. E., Gare, S. G., and Dennis, P. F.: Unusual isotopic phenomena in Welsh quarry water and carbonate crusts, Terr. Nova, 9, 67-70, 1997.

Bayari, C. S. and Kurttas, T.: Algae: An important agent in deposition of karstic travertines: Observations on natural-bridge Yerkopru travertines, Aladaglar, Eastern Taurids, Turkey, 5th International Symposium and Field Seminar on Karst Waters and Environmental Impacts, Antalya, Turkey, ISI:A1997BH23Q00034, 269-280, 1995.

Bissett, A., DeBeer, D., Schoon, R., Shiraishi, F., Reimer, A., and Arp, G.: Microbial mediation of tufa formation in karst-water creeks., Limnol. Oceanogr., 53, 1159-1168, 2008a.

Bissett, A., Reimer, A., de Beer, D., Shiraishi, F., and Arp, G.: Metabolic Microenvironmental Control by Photosynthetic Biofilms under Changing Macroenvironmental Temperature and pH Conditions, Appl. Environ. Microbiol., 74, 6306-6312, 2008b.

Blanchard, G. F., Guarini, J. M., Richard, P., Gros, P., and Mornet, F.: Quantifying the short-term temperature effect on lightsaturated photosynthesis of intertidal microphytobenthos, Mar. Ecol.-Prog. Ser., 134, 309-313, 1996.

Brasier, A. T.: Archaean Soils, Lakes and Springs: Looking for Signs of Life, in: Evolution of Archean Crust and Early Life, edited by: Dilek, Y. and Furnes, H., Modern Approaches in Solid Earth Sciences, Springer Netherlands, the Netherlands, 367-384, 2014.

Brasier, A. T., Andrews, J. E., and Kendall, A. C.: Diagenesis or dire genesis? The origin of columnar spar in tufa stromatolites of central Greece and the role of chironomid larvae, Sedimentology, 58, 1283-1302, 2011.

Buccino, G., D’Argenio, B., Ferreri, V., Brancaccio, L., Ferreri, M., Panachi, C., and Stazione, D.: I travertini della basse valle del Tanagro (Campania), Studio geomorphologico, sedimentologico e geochimico, Boll. Soc. Geol. Ital., 97, 617-646, 1978.

Carrara, C.: I travertini di Canino (Viterbo, Italia Centrale): elementi di cronolitostratigrafia, di geochimica isotopica e loro significato ambientale e climatico, Quaternario, 7, 73-90, 1994.

Carrara, C., Ciufarella, L., and Paganin, G.: Inquadramento geomorfologico e climatico-ambientale dei travertini di Rapolano Terme (SI), Quaternario, 11, 3119-3329, 1998.

Carthew, K. D., Taylor, M. P., and Drysdale, R. N.: An environmental model of fluvial tufas in the monsoonal tropics, Barkly karst, northern Australia, Geomorphology, 73, 78-100, 2006.

Chafetz, H. S. and Folk, R. L.: Travertines - Depositional morphology and the bacterially controlled constituents, J. Sediment Petrol., 54, 289-316, 1984. 
Chafetz, H. S. and Guidry, S. A.: Deposition and diagenesis of Mammoth Hot Springs travertine, Yellowstone National Park, Wyoming, USA, Can. J. Earth Sci., 40, 1515-1529, 2003.

Chen, J. A., Zhang, D. D., Wang, S. J., Xiao, T. F., and Huang, R. G.: Factors controlling tufa deposition in natural waters at waterfall sites, Sediment. Geol., 166, 353-366, 2004.

Clark, I. D. and Fontes, J. C.: Paleoclimatic reconstruction in Northern Oman based on carbonates from hyperalklaine groundwaters, Quat. Res., 33, 320-336, 1990.

D'Argenio, B. and Ferreri, V.: Ambiente di deposizione e litofacies dei travertino quaternari dell' Italia centrale-meridionale, Mem Soc. Geol. It., 41, 861-868, 1988.

Dandurand, J. L., Gout, R., Hoefs, J., Menschel, G., Schott, J., and Usdowski, E.: Kinetically controlled variations of major components and carbon and oxygen isotopes in a calcite-precipitating spring, Chem. Geol., 36, 299-315, 1982.

Decho, A. W.: Overview of biopolymer-induced mineralization: What goes on in biofilms?, Ecol. Engin., 36, 137-144, 2010.

Dittrich, M. and Sibler, S.: Calcium carbonate precipitation by cyanobacterial polysaccarides, in: Speleothems and Tufas: Unravelling Physical and Biological controls, edited by: Pedley, $\mathrm{H}$. M. and Rogerson, M., Geological Society of London Special Publication, Geological Society of London, London, 2010.

Dramis, F., Materazzi, M., and Cilla, G.: Influence of climate change on freshwater travertine deposition: a new hypothesis, Physical, Chem. Earth, 24, 893-897, 1999.

Dreybrodt, W. and Buhmann, D.: A mass-transfer model for dissolution and precipitation of calcite from solutions in turbulent motion, Chem. Geol., 90, 107-122, 1991.

Dreybrodt, W., Eisenlohr, L., Madry, B., and Ringer, S.: Precipitation kinetics of calcite in the system $\mathrm{CaCO}_{3}-\mathrm{H}_{2} \mathrm{O}-\mathrm{CO}_{2}$ : The conversion to $\mathrm{CO}_{2}$ by the slow process $\mathrm{H}+\mathrm{HCO}_{3}->\mathrm{CO}_{2}+\mathrm{H}_{2} \mathrm{O}$ as a rate limiting step, Geochimica Et Cosmochimica Acta, 61, 38973904, 1997.

Drysdale, R., Lucas, S., and Carthew, K.: The influence of diurnal temperatures on the hydrochemistry of a tufa-depositing stream, Hydrol. Process., 17, 3421-3441, 2003a.

Drysdale, R. N. and Gale, S. J.: The Indarri Falls travertine dam, Lawn Hill Creek, northwest Queensland, Australia, Earth Surface Processes and Landforms, 22, 413-418, 1997.

Drysdale, R. N., Carthew, K. D., and Taylor, M. P.: Larval caddis-fly nets and retreats: a unique biosedimentary paleocurrent indicator for fossil tufa deposits, Sediment. Geol., 161, 207-215, 2003.

Dunham, R. J.: Classification of carbonate rocks according to depositional texture., in: Classification of Carbonate Rocks, edited by: Ham, W. E., Am. Assoc. Petrol. Geol., , Tulsa, Oklahoma, 108-121, 1962.

Dupraz, C., Reid, R. P., Braissant, O., Decho, A. W., Norman, R. S., and Visscher, P. T.: Processes of carbonate precipitation in modern microbial mats, Earth-Science Reviews, 96, 141-162, 2009.

Embrey, A. F. and Kloven, E. J.: Absolute water depth limits of Late Devonian paleoecological zones, Geol. Rundsch., 61, 1972.

Emeis, K. C., Richnow, H. H., and Kempe, S.: Travertine Formation in Plitvice-National-Park, Yugoslavia - Chemical Versus Biological-Control, Sedimentology, 34, 595-609, 1987.

Eremin, A., Bulychev, A., Krupenina, N. A., Mair, T., Hauser, M. J. B., Stannarius, R., Muller, S. C., and Rubin, A. B.: Excitationinduced dynamics of external $\mathrm{pH}$ pattern in Chara corallina cells and its dependence on external calcium concentration, Photochem. Photobio. Sci., 6, 103-109, 2007.

Ferreri, V.: Criteri di analisi facies e classificazione dei travertini pleistocenici dell'Italia meridionale., Rend. Acc. Sci. Fis. Mat. Serie, 4, 1-47, 1985.

Folk, R. L.: Practical petrographic classification for limestones., Bull. Amer. Assoc. Petroleum Geologists., 43, 1-38, 1959.

Folk, R. L.: Interaction between bacteria, nannobacteria and mineral precipitation in hot springs of Central Italy., Geogr. Phys. Quatern., 48, 233-246, 1994.

Folk, R. L. and Chafetz, H. S.: Pisoliths (pisoids) in Quaternary travertines of Tivoli, Italy, in: Coated Grains, edited by: Peryt, T. M., Springer-Verlag, Berlin, 474-487, 1983.

Folk, R. L., Chafetz, H. S., and Tiezzi, P. A.: Bizarre forms of depositional and diagenetic calcite in hot spring travertines, central Italy, in: Carbonate Cements Soc., edited by: N.B.Schneidmann, and Harris, P., Econ. Paleont. Miner. Spec. Publ., 349-369, 1985.

Ford, T. D. and Pedley, H. M.: A review of tufa and travertine deposits of the world, Earth-Sci. Rev., 41, 117-175, 1996.

Ford, T. D. and Pedley, H. M.: Tufa and travertine deposits of the Grand Canyon, Cave and Karst Science, 24, 107-116, 1997.

Fouke, B. W., Farmer, J. D., Marais, D. J. D., Pratt, L., Sturchio, N. C., Burns, P. C., and Discipulo, M. K.: Depositional Facies and Aqueous-Solid Geochemistry of Travertine-Depositing Hot Springs (Angel Terrace, Mammoth Hot Springs, Yellowstone National Park, USA), J. Sediment. Res., 70, 565-585, 2000.

Fouke, B. W., Bonheyo, G. T., Sanzenbacher, B., and Frias-Lopez, J.: Partitioning of bacterial communities between travertine depositional facies at Mammoth Hot Springs, Yellowstone National Park, USA, Can. J. Earth Sci., 40, 1531-1548, 2003.

Frisia, S., Borsato, A., Fairchild, I. J., and McDermott, F.: Calcite Fabrics, Growth Mechanisms, and Environments of Formation in Speleothems from the Italian Alps and Southwestern Ireland, J. Sediment. Res., 70, 1183-1196, 2000.

Glover, C. and Robertson, A. F. H.: Origin of tufa (cool water carbonate) and related terraces in the Antalya area, edited by: S. W. Turkey, Geol. J., 38, 329-358, 2003.

Golubić, S.: Cyclic and non-cyclic mechanisms in the formation of travertine., Verh. Int. Ver.Theor. Ang. Limnol., 17, 956-961, 1969.

Golubić, S., Violante, C., Ferreri, V., and D'Argenio, B.: Algal control and early diagenesis in Quaternary travertine formation (Rocchetta a Volturno, Central Apennines., in: Studies on Fossil Benthic Algae, edited by: Barattolo, F., Boll. Soc. Paleontol. Ital., Spec. vol., 231-247, 1993.

Guo, L. and Riding, R.: Hot spring travertine facies and sequences, Late Pleistocene Rapolano Terme, Italy, Sedimentology, 45, 163-180, 1998.

Hagele, D., Leinfelder, R., Grau, J., Burmeister, E. G., and Struck, U.: Oncolds from the river Alz (southern Germany): Tiny ecosystems in a phosphorus-limited environment, Palaeogeogr. Palaeoclimat. Palaeoecol., 237, 378-395, 2006.

Hammer, O.: Watch your step, Nature Physics, 4, 265-266, 2008.

Hammer, O., Dysthe, D. K., and Jamtveit, B.: The dynamics of travertine dams, Earth Planet. Sci. Lett., 256, 258-263, 2007.

Hammer, O., Dysthe, D. K., Lelu, B., Lund, H., Meakin, P., and Jamtveit, B.: Calcite precipitation instability under laminar, open-channel flow, Geochimica Et Cosmochimica Acta, 72, 5009-5021, 2008. 
Hammer, Ø., Dysthe, D. K., and Jamtveit, B.: Travertine terracing: patterns and mechanisms, Geological Society, London, Special Publications, 336, 345-355, 2010.

Hobbie, J. E., Daley, R. J., and Jasper, S.: Use of Nuclepore filters for counting bacteria by fluorescence microscopy, Appl. Environ. Microbiol., 33, 1225-1228, 1977.

Hori, M., Hoshino, K., Okumura, K., and Kano, A.: Seasonal patterns of carbon chemistry and isotopes in tufa depositing groundwaters of southwestern Japan, Geochimica Et Cosmochimica Acta, 72, 480-492, 2008.

Inskeep, W. P. and Bloom, P. R.: An evaluation of rate equations for calcite precipitation kinetics at pCO2 less than $0.01 \mathrm{~atm}$ and pH greater than 8 Geochimica et Cosmochimica Acta, 49, 21652180, 1985.

Irion, and Müller, G.: Mineralogy, petrology and chemical composition of some calcareous tufa from Swabische Alb, Germany, in: Recent developments in carbonate sedimentology in Central Europe, edited by: Müller, G., and Freidman, G. M., SpringerVerlag, 156-171, 1968.

Jones, B. and Renaut, R. W.: Calcareous Spring Deposits in Continental Settings, Sedimentology, 61, 177-224, 2010.

Jones, B., Renaut, R. W., and Rosen, M. R.: Microbial biofacies in hot-spring sinters: a model based on Ohaaki Pool, North island, New Zealand, J. Sediment. Res., 68, 413-434, 1998.

Julia, R.: Travertines, in: Carbonate Depositional Environments, edited by: Schole, P. A., Bebout, D. G., and Moore, C., AAPG Mem., 64-72, 1983.

Kawaguchi, T. and Decho, A. W.: Isolation and biochemical characterization of extracellular polymeric secretions (EPS) from modern soft marine stromatolites (Bahamas) and its inhibitory effect on $\mathrm{CaCO}_{3}$ precipitation, Preparat. Biochem. Biotechnol., 32, 5163, 2002.

Kent, P., Gaunt, G. D., and Wood, C. J.: British Regional Geology, Eastern England from the Tees to the Wash. 2nd edition., Institute of Geological Sciences, Natural Environ. Res. Council, HMSO, London, 1980.

Kupriyanova, E., Villarejo, A., Markelova, A., Gerasimenko, L., Zavarzin, G., Samuelsson, G., Los, D. A., and Pronina, N.: Extracellular carbonic anhydrases of the stromatolite-forming cyanobacterium Microcoleus chthonoplastes, Microbiology, 153, 1149-1156, 2007.

Kupriyanova, E. V., Lebedeva, N. V., Dudoladova, M. V., Gerasimenko, L. M., Alekseeva, S. G., Pronina, N. A., and Zavarzin, G. A.: Carbonic anhydrase activity of alkalophilic cyanobacteria from soda lakes, Russ. J. Plant Physiol., 50, 532-539, 2003.

Langmuir, D.: Aqueous Environmental Geochemistry, PrenticeHall Inc., Upper Saddle River, New Jersey, 600 pp., 1997.

Ledger, M. E., Harris, R. M. L., Armitage, P. D., and Milner, A. M.: Disturbance frequency influences patch dynamics in stream benthic algal communities, Oecologia, 155, 809-819, 2008.

Li, W., Yu, L. J., Yuan, D. X., Wu, Y., and Zeng, X. D.: A study of the activity and ecological significance of carbonic anhydrase from soil and its microbes from different karst ecosystems of Southwest China, Plant Soil, 272, 133-141, 2005.

Li, W., Yu, L. J., Wu, Y., Jia, L. P., and Yuan, D. X.: Enhancement of $\mathrm{Ca} 2+$ release from limestone by microbial extracellular carbonic anhydrase, Bioresource Technol., 98, 950-953, 2007.

Liu, Z., Dreybrodt, W., and Wang, H.: A new direction in effective accounting for the atmospheric $\mathrm{CO}_{2}$ budget: Considering the combined action of carbonate dissolution, the global water cycle and photosynthetic uptake of DIC by aquatic organisms, EarthSci. Rev., 99, 162-172, 2010.

Liu, Z. H. and Dreybrodt, W.: Dissolution kinetics of calcium carbonate minerals in $\mathrm{H}_{2} \mathrm{O}-\mathrm{CO}_{2}$ solutions in turbulent flow: The role of the diffusion boundary layer and the slow reaction $\mathrm{H}_{2} \mathrm{O}+\mathrm{CO}_{2}$ reversible arrow $\mathrm{H}++\mathrm{HCO} 3$, Geochimica Et Cosmochimica Acta, 61, 2879-2889, 1997.

Liu, Z. H., Liu, X.L., and Liao, C. J.: Daytime deposition and nighttime dissolution of calcium carbonate controlled by submerged plants in a karst spring-fed pool: insights from high timeresolution monitoring of physico-chemistry of water, Environ. Geol., 55, 1159-1168, 2008.

Lorah, M. M. and Herman, J. S.: The chemical evolution of a Travertine-depositing stream: geochemical processes and mass transfer reactions, Water Resour. Res., 24, 1541-1552, 1988.

Lowenstam, H. A.: Minerals formed by organisms, Science, 211, 1126-1131, 1981.

Marks, J. C., Parnell, R., Carter, C., Dinger, E. C., and Haden, G. A.: Interactions between geomorphology and ecosystem processes in travertine streams: Implications for decommissioning a dam on Fossil Creek, Arizona, Geomorphology, 77, 299-307, 2006.

Mayes, W. M., Younger, P. L., and Aumonier, J.: Hydrogeochemistry of alkaline steel slag leachates in the UK, Water Air Soil Pollut., 195, 35-50, 2008.

Merz-Preiss, M. and Riding, R.: Cyanobacterial tufa calcification in two freshwater streams: ambient environment, chemical thresholds and biological processes, Sedimentary Geol., 126, 103-124, 1999.

Minissale, A.: Origin, transport and discharge of $\mathrm{CO}_{2}$ in central Italy, Earth-Sci. Rev., 66, 89-141, 2004.

Newton, M. S.: Holocene fluctations of Mono Lake, California: the sedimentary record, in: Sedimentology and Geochemistry of Modern and Ancient Saline Lakes, edited by: Renaut, R. W. and Last., W. M., SEPM Special Publications, SEPM, 143-157, 1994.

Nicod, J.: Repartition, classification, relation avec les milieux karstiques et karstification, Bull. Assoc. Geogr. Fr, 479/480, 181$187,1981$.

Patterson, C. S., Busey, R. H., and Mesmer, R. E.: Second ionization of carbonic acid in $\mathrm{NaCl}$ media to $250^{\circ} \mathrm{C}$, J. Solut. Chem., 13, 647-661, 1984.

Pedley, H. M.: Classification and environmental models of cool freshwater tufas, Sediment. Geol., 68, 143-154, 1990.

Pedley, H. M.: Prokaryote microphyte biofilms: a sedimentological perspective, Kaupia, Darmstader Betr. Naturgesh., 4, 45-60, 1994.

Pedley, H. M.: Tufas and travertines of the Mediterranean region: a testing ground for freshwater carbonate concepts and developments, Sedimentology, 56, 221-246, 2009.

Pedley, H. M. and Rogerson, M.: Introduction to tufas and speleothems, in: Speleothems and Tufas: Unravelling Physical and Biological controls, edited by: Pedley, H. M., and Rogerson, M., Geologicasl Society Special Publication, Geological Society, London, 2010a.

Pedley, H. M. and Rogerson, M.: In vitro investigations of the impact of different temperature and flow velocity conditions on tufa microfabric., in: Speleothems and Tufas: Unravelling Physical and Biological controls, edited by: Pedley, H. M., and Rogerson, 
M., Geological Society Special Publication, Geological Society of London, London, 193-210, 2010b.

Pedley, H. M., Rogerson, M., and Middleton, R.: The growth and morphology of freshwater calcite precipitates from in Vitro Mesocosm flume experiments; the case for biomediation, Sedimentology, 56, 511-527, 2009.

Pedley, M.: Fresh-Water (Phytoherm) Reefs - the Role of Biofilms and Their Bearing on Marine Reef Cementation, Sediment. Geol., 79, 255-274, 1992.

Pedley, M., Andrews, J., Ordonez, S., delCura, M. A. G., Martin, J. A. G., and Taylor, D.: Does climate control the morphological fabric of freshwater carbonates?, A comparative study of Holocene barrage tufas from Spain and Britain, Palaeogeogr. Palaeoclimat. Palaeoecol., 121, 239-257, 1996.

Peña, J.L., Sancho, C., and Lozano, M. V.: Climatic and tectonic significance of late Pleistocene and Holocene tufa deposits in the Mijares River canyon, eastern Iberian range, northeastern Spain., Earth Surf. Proc. Land., 25, 1403-1417, 2000.

Pentecost, A.: Blue-green-algae and freshwater carbonate deposits, Proceedings of the Royal Society of London Series B-Biological Sciences, 200, 43-61, 1978.

Pentecost, A.: Growth and calcification of the fresh-water cyanobacterium Rivularia haematites, Proceedings of the Royal Society of London Series B-Biological Sciences, 232, 125-136, 1987.

Pentecost, A.: Carbonate chemistry of surface waters in a temperature karst region - the southern Yorkshire Dales, UK., J. Hydrol., 139, 211-232, 1992

Pentecost, A.: Travertine, Springer, Berlin, 2005.

Pentecost, A. and Lord, T. C.: Postglacial tufas and travertines from the Craven district Yorkshire., Cave Science,, 15, 15-19, 1988.

Pentecost, A. and Viles, H. A.: A review and reassessment of travertine classification. , Géogr. Phys. Quaternaire, 48, 305-314, 1994.

Pentecost, A., Andrews, J. E., Dennis, P. F., Marca-Bell, A., and Dennis, S.: Charophyte growth in small temperate water bodies: Extreme isotopic disequilibrium and implications for the palaeoecology of shallow marl lakes, Palaeogeogr.Palaeoclimat. Palaeoecol., 240, 389-404, 2006.

Peryt, T. M.: Oncoids, Comments on recent developments, in: Coated Grains, edited by: Peryt, T. M., Springer-Verlag, Berlin, Heidelburg, 273-275, 1983.

Plummer, L. N. and Busenberg, E.: The solubilities of calcite, aragonite and vaterite in $\mathrm{CO}_{2}-\mathrm{H}_{2} \mathrm{O}$ solutions between 0 and $90^{\circ} \mathrm{C}$, and an evaluation of the aqueous model for the system $\mathrm{CaCO}_{3}$ $\mathrm{CO}_{2}-\mathrm{H}_{2} \mathrm{O}$, Geochimica Et Cosmochimica Acta, 46, 1011-1040, 1982.

Renaut, R. W. and Jones, B.: Controls on aragonite and calcite precipitation in hot spring travertines at Chemurkeu, Lake Bogoria, Kenya, Can. J. Earth Sci., 34, 801-818, 1997.

Riding, R.: Chapter 2, Classification of microbial carbonates, in: Calcareous Algae and Stromatolites, edited by: Riding, R., Springer-Verlag, Berlin, Heidelburg, 21-51, 1991.

Rogerson, M., Pedley, H. M., Wadhawan, J. D., and Middleton, R.: New Insights into Biological Influence on the Geochemistry of Freshwater Carbonate Deposits, Geochimica et Cosmochimica Acta, 72, 4976-4987, 2008.

Rogerson, M., Pedley, H. M., and Middleton, R.: Microbial Influence on Macroenvironment Chemical Conditions in Alka- line (Tufa) Streams; Perspectives from In Vitro Experiments, in: Speleothems and Tufas: Unravelling Physical and Biological controls, edited by: Pedley, H. M., and Rogerson, M., Geological Society Special Publication, Geological Society of London, London, 65-81, 2010.

Saunders, P. V., Rogerson, M., Pedley, H. M., Wadhawan, J., and Greenway, G.: $\mathrm{Mg} / \mathrm{Ca}$ ratios in freshwater microbial carbonates: Thermodynamic, Kinetic and Vital Effects., Geochimica Et Cosmochimica Acta, in review, 2014.

Schneider, J., Schneider, H. G., Campion, S. L., and Alsumard, T.: Algal micro-reefs-coated grains from freshwater environments, in: Coated Grains, edited by: T.M. Peryt, Springer, Berlin, 284298, 1983.

Shiraishi, F., Bissett, A., de Beer, D., Reimer, A., and Arp, G.: Photosynthesis, respiration and exopolymer calcium-binding in biofilm calcification (Westerhfer and deinschwanger creek, germany), Geomicrobiol. J., 25, 83-94, 2008a.

Shiraishi, F., Reimer, A., Bissett, A., de Beer, D., and Arp, G.: Microbial effects on biofilm calcification, ambient water chemistry and stable isotope records in a highly supersaturated setting (Westerhofer Bach, Germany), Palaeogeogr. Palaeoclimat. Palaeoecol., 262, 91-106, 2008b.

Shiraishi, F., Zippel, B., Neu, T. R., and Arp, G.: In situ detection of bacteria in calcified biofilms using FISH and CARD-FISH, J. Microbiol. Methods, 75, 103-108, 2008c.

Spiro, B. and Pentecost, A.: One Day in the Life of a Stream - a Diurnal Inorganic Carbon Mass Balance for a TravertineDepositing Stream (Waterfall Beck, Yorkshire), Geomicrobiol. J., 9, 1-11, 1991.

Stirn, A.: Kalktuffvorkommen und Kalktufftypen der Schwäbischen Alb, Abh. Karst Höhlenknd, 1-91, 1964.

Symoens, J. J., Duvigneaud, P., and van den Bergen, C.: Aperçu sur la végétation des tufs calcaires de la Belgique, Bull. Soc. R. Bot. Belg., 83, 329-352, 1951.

Szulc, J.: Genesis and classification of travertine deposits, Przegl. Geol., 31, 2311-2236, 1983.

Veysey, J. and Goldenfeld, N.: Watching rocks grow, Nature Physics, 4, 310-313, 2008.

Veysey II, J., Fouke, B. W., Kandianis, M. T., Schickel, T. J., Johnson, R. W., and Goldenfeld, N.: Reconstruction of Water Temperature, $\mathrm{pH}$, and Flux of Ancient Hot Springs from Travertine Depositional Facies, J. Sediment. Res., 78, 69-76, 2008.

Visscher, P. T. and Stolz, J. F.: Microbial mats as bioreactors: populations, processes, and products, Palaeogeogr. Palaeoclimat. Palaeoecol., 219, 87-100, 2005.

Wingender, J., Neu, T., and Flemming, H.-C.: What are Bacterial Extracellular Polymeric Substances?, in: Microbial Extracellular Polymeric Substances, edited by: Wingender, J., Neu, T., and Flemming, H.-C., Springer Berlin Heidelberg, 1-19, 1999.

Wright, V. P.: Lacustrine carbonates in rift settings: the interaction of volcanic and microbial processes on carbonate deposition, Geological Society, London, Special Publications, 370, 39-47, 2012.

Zaihua, L., Svensson, U., Dreybrodt, W., Daoxian, Y., and Buhmann, D.: Hydrodynamic control of inorganic calcite precipitation in Huanglong Ravine, China: Field measurements and theoretical prediction of deposition rates Geochimica et Cosmochimica Acta, 59, 3087-3097, 1995. 